\title{
Josef Plojhar a rok 1968. Konec jedné ministerské kariéry ${ }^{1}$
}

\section{MICHAL PEHR}

\begin{abstract}
Josef Plojhar and the year 1968. The end of one minister's career
Catholic priest and chairman of the Czechoslovak People's Party, and supreme functionary of the Board of pro-regime organisations (e.g. long-term vice-chairman of the Association of Czechoslovak Soviet Friendship), Josef Plojhar, was a distinctive figure in the political world of Communist Czechoslovakia during the first twenty years of its existence. He was one of the historically longest serving ministers of health and spent an unbelievable twenty years and one month in this position. He survived a number of political upheavals and purges within the terms of post-February Czechoslovakia. All this makes him an indisputably interesting figure, who has been neglected by previous historic research. This study is about the end of the climactic political career of this Catholic priest and chairman of the Czechoslovak People's Party, who was Minister of Health from 1948 to 1968. His political downfall came about in connection with the Prague Spring in 1968.
\end{abstract}

KeY wORDS: Czechoslovakia 1968 - Czechoslovak People's Party - Josef Plojhar (1902-1981)

Contacts: PhDr. Michal Pehr, Ph.D., ÚSTR, Nám. Winstona Churchilla 1800/2, 13000 Praha 3; e-mail: michal. pehr@post.cz

Katolický kněz a předseda Československé strany lidové Josef Plojhar a vrcholný činovník řady prorežimních organizací (např. dlouholetý místopředseda Svazu československo-sovětského přátelství) patřil mezi výrazné postavy politického světa komunistického Československa v prvních dvaceti letech jeho existence. ${ }^{2}$ Patřil mezi historicky nejdéle sloužící ministry zdravotnictví. V této funkci strávil neuvěřitelných dvacet let a jeden měsíc. Přežil

1 Tento text je jedním z výstupů projektu č. 57 Biografie Josefa Plojhara 1902-1981 řešeného na Ústavu pro studium totalitních režimů týmem Stanislavy Vodičkové a Michala Pehra.

2 Josef Plojhar(1902-1981), kněz a politik. Pocházel z česko-německé rodiny. 1925 vysvěcen na kněze a následně působil jako duchovní v českobudějovické diecézi. Angažoval se v katolických spolcích, v Československé straně lidové a přispíval svými články do regionálního tisku. 1939 zatčen a 1939-1945 vězněn v koncentračních táborech Buchenwald a Dachau. Po válce se angažoval v politice. 1945-1948 poslanec PNS a ÚNS. V únoru 1948 přijal nabídku Klementa Gottwalda a stal se ministrem zdravotnictví. 1948-1968 ministr zdravotnictví a poslanec NS; 1951-1968 předseda ČSL a Celostátního mírového duchovenstva. Za svoji politickou činnost po únoru 1948 byl katolickou církví suspendován. Z literatury k jeho osobě blíže viz např́klad Michal PEHR a kol., Cestami křest'anské politiky, Praha 2007, s. 198-199. Z jeho vlastní literární tvorby blíže viz např. Josef Plojhar, O stigmatisované Terezii Neumannové z Konnersreuthu, České Budějovice 1928; TÝž, Za mír a socialismus: projevy a stati z let 1950-52, Praha 1953; TÝž, Vitězný únor a Čs. strana lidová, Praha 1958; TÝž, Křest’ané a socialismus, Praha 1961; TÝž, Společná cesta. Jeden cíl. Sborník projevů a článků J. Plojhara (uspořádal František Touška a předmluvu napsal Rostislav Petera), Praha 1963; TÝž, Křest’ané a socialismus, Praha 1971. 
řadu politických otřesů a čistek v rámci poúnorového Československa. To všechno z něj dělá nesporně zajímavou postavu, která prozatím stála stranou historického výzkumu. Cílem této studie je pak přiblížit jeho politický pád v souvislosti s pražským jarem 1968.

Konec Josefa Plojhara v nejvyšších stranických a vládních funkcí chnastal nečekaně. $\mathrm{S}$ jistou nadsázkou řečeno tak, jako se překvapivě stal ministrem zdravotnictví v únoru 1948, tak nečekaně nastal i jeho politický konec v nejvyšších patrech československé politiky. Ale nepředbíhejme.

Počátek pražského jara bývá tradičně spojován s koncem Antonína Novotného v čele KSČ. ${ }^{3}$ Na lednovém zasedaní ÚV KSČ byl Antonín Novotný vystřídán Alexandrem Dubčekem ${ }^{4}$ a tato změna vyvolala celospolečenské hnutí, které vedlo k pokusům o celkovou liberalizaci stávajícího komunistického systému, všeobecně označované jako pokus o vytvoření socialismu s lidskou tváří nebo také pražské jaro. ${ }^{5}$

Politické změny se následně a s jistým zpožděním odrazily i v lidové straně, která vedle socialistické strany byla tolerovanou politickou stranou v rámci systému Národní fronty. ${ }^{6}$ Vedení lidové strany v čele s Josefem Plojharem bylo tehdy překotným vývojem do jisté míry zaskočeno. Politické změny zastihly stranu a její vedení naprosto nepřipravené. První týdny roku 1968 se nesly ve vedení ČSL ve znamení jistého mlčení a vyčkávání, co přinese budoucnost. Tak to nazval jeden z výrazných funkcionářů ČSL Václav Pacner, ${ }^{7}$ který hovořil na sklonku března 1968 o tom, že od ledna celá strana mlčela. ${ }^{8}$ Procházíme-li kupř́kladu stranický tisk té doby, tak přijdeme na to, že Pacnerovo hodnocení bylo více než příhodné. Stranické vedení opravdu na začátku roku mlčelo a v podstatě takticky vyčkávalo. A tak v prvních dnech a týdnech klíčového roku 1968 se můžeme setkat s neutrálními komentáři či př́ípadně tématy, která nesouvisela s politickým vývojem v zemi.

Josef Plojhar se v lednu 1968 například často vyjadřoval k návštěvě amerického pre-

3 Antonín Josef Novotný (1904-1974), komunistický funkcionář a politik. V mládí se vyučil strojním zámečníkem a pracoval jako dělník v řadě pražských továren (např. ČKD Vysočany a ČKD Libeň). Od roku 1921 člen KSČ, kde zastával řadu nejrůznějších funkcí v rámci pražské krajské organizace KSČ. 1937-1938 tajemník KV KSČ v Hodoníně. 1939-1941 zaměstnán v družstvu Včela v Praze-Vysočanech a zároveň se zapojil do činnosti ilegální KSČ. 1941-1945 vězněn v koncentračním táboře Mauthausen. Po osvobození 1945-1951 působil jako krajský tajemník KSČ v Praze; 1946-1968 člen ÚV KSČ; 1951-1953 tajemník ÚV KSČ a 1953-1968 první tajemník ÚV KSČ; 1948-1957 poslanec NS a 1953 náměstek předsedy vlády. 1957-1968 prezident ČSR (ČSSR) a 1959-1968 předseda ÚV NF.

4 Srovnej Rudé právo, roč. 48, č. 5, 6. ledna 1968, s. 1, článek Zpráva o zasedání ústředního výboru Komunistické strany Československa.

5 Z literatury k problematice pražského jara blíže viz např. Vojtěch MencL a kol., Osm měsiců pražského jara 1968, Praha 1968; Petr Pithart, Osmašedesátý, Praha 1990 a Martin Schulze Wessel, Pražské jaro: průlom do nového světa, Praha 2018.

6 Z literatury k dějinám ČSL ve sledovaném období blíže viz např. Karel KonEČNÝ, Československá strana lidová v obdobi nastupujici normalizace (1969-1972), Praha 2019.

7 Václav Pacner (1917-1998), úředník a politik. 1932-1934 absolvoval odbornou školu knihkupeckou a nakladatelskou. Řadu let pracoval v nejrůznějších nakladatelstvích jako referent a redaktor právnických časopisů a publikací. 1940-1945 vězněn nacisty za války. Od roku 1945 člen ČSL. Politicky angažovat se začal až po únoru 1948 a postupně se stával reprezentantem poúnorové obrozené strany v Praze. 1965-1968 ústřední tajemník ČSL a 1957-1964 poslanec ÚNV Praha respektive NV hlavního města Prahy. 1964-1971 poslanec NS a SL FS; 1970-1976 ředitel vydavatelství a nakladatelství Lidová demokracie.

8 Archiv KDU-ČSL, fond ÚV ČSL, nezpracováno. Na zasedání ÚV ČSL 31. března 1968 k tomu podle záznamu řekl: „LD mlčela, mlčelo PÚV, mlčely kraje, mlčely okresy, soudím, že každýz nás má na tomto velikém mlčení svi̊j podil. Někdo větší. Někdo menši “. 


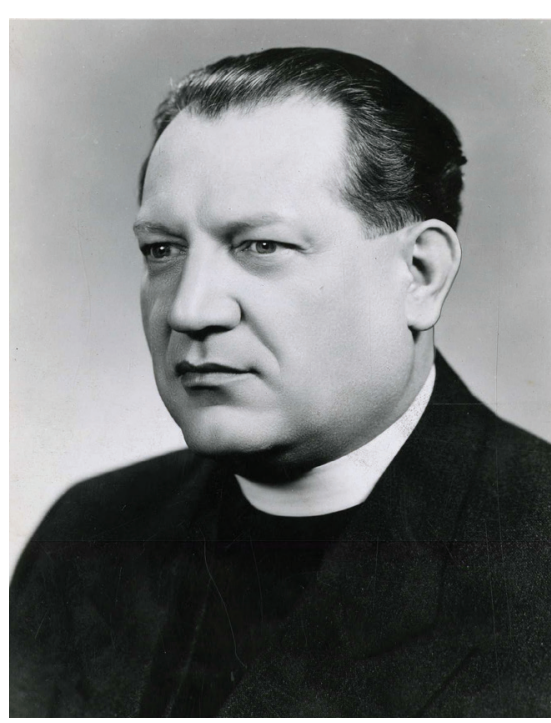

Obrázek 1 - Oficiální portrétni fotografie J. Plojhara. ANM, f. PNP-osoby, i. č. 2681. zidenta Johnsona v Rímě, kterého primárně kritizoval za činnost USA ve Vietnamu. ,Johnson... $v$ Řimě nepochodil. Naopak. Sotva se president vrátil domů, obnovilo letectvo Spojených státu bombardování demokratického Vietnamu ještě $s$ větši intenzitou... svět se dnes víc než kdykoliv dřvive může jasně presvědčit, kdo to myslí s budoucností lidstva upř́mně. "9 Mimo to se Plojhar vyjadřoval $\mathrm{k}$ různým dalším otázkám zahraniční politiky ve spojitosti s katolickou církví a křest'anskými stranami ${ }^{10}$ nebo vzpomínal na dobu druhé světové války a připomínal její hrůzy a nacistické běsnění. ${ }^{11}$

Pokud se vedení strany v tomto období vyjadřovalo k vnitropolitické situaci, tak jeho vyjádření byla v podstatě bezobsažná. Změnu ve vedení KSČ lidovci okomentovali tak, že strana ,přispěje pod vedením KSČ co nejaktivněji a s naď̌ením k rozvoji naši socialistické společnosti a výstavbě vlasti “.12 V podobném duchu byla komentována i schůze předsedy Plojhara s předsedou socialistů A. Neumanem a Alexandrem Dubčekem 11. ledna 1968. ${ }^{13}$

Tak tomu bylo jak v lednu 1968, tak v únoru 1968, kdy se do popředí dostávalo dvacáté výročí únorových změn. Oslavy vítězného února byly v zásadě poslední událostí, kdy staré vedení strany oslavovalo ještě v časech relativního klidu. Josef Plojhar promlouval na toto téma při řadě nejrůznějších oslavách, které byly při prríležitosti tohoto výročí organizovány. Například na slavnostním zasedání rozšířeného ústředního výboru Mírového hnutí katolického duchovenstva, kde v duchu svých dosavadních projevů ujišt'oval: ,,povedeme i nadále naše věřci k tomu, aby byli aktivními spolutvưrci št'astné budoucnosti naši vlasti. Budeme neustále posilovat žulovou jednotu Čechů a Slováků. Sještě větším elánem chceme přispívat k posílení a upevnění míru na celém světě “. ${ }^{14} \mathrm{~A} v$ podobném duchu probíhají i setkání vedení ČSL, které 16. a 17. února na slavnostním zasedání ÚV ČSL vyznamenávalo své zasloužilé členy, a slavilo se jak jinak než pod taktovkou zasloužilého předsedy. Tyto únorové oslavy však byly pověstnou labutí písní stávajícího vedení. Josef Plojhar pak ve stejném duchu ještě napsal 25. února 1968 do Lidové demokracie článek Významný mezník novodobých

9 Lidová demokracie, roč. 24, č. 6, 7. ledna 1968, s. 1, článek J. Plojhara Johnson v Římě. V podobném duchu vyzníval i Plojharův úvodní sloupek 14. ledna 1968. Blíže viz Lidová demokracie, roč. 24, č. 13, 14. ledna 1968, s. 1, článek Josefa Plojhara Vlk a Jehně.

10 Lidová demokracie, roč. 24, č. 20, 21. ledna 1968, s. 1, článek J. Plojhara Polští katolíci; Lidová demokracie, roč. 24, č. 27, 28. ledna 1968, článek J. Plojhara Caprichos Frankovy justice; Lidová demokracie, roč. 24, č. 41, 11. února 1968, s. 1, článek J. Plojhara Afrika a Vatikán.

11 Lidová demokracie, roč. 24, č. 34, 4. února 1968, článek Josefa Plojhara Vrahové dětí.

12 Lidová demokracie, roč. 24, č. 9. 10. ledna 1968, s. 1, článek Ze zasedání předsednictva ČSL.

13 Lidová demokracie, roč. 24, č. 11, 12. ledna 1968, s. 1, článek Předsedové stran NF u A. Dubčeka.

14 Lidová demokracie, roč. 24, č. 46, 16. února, s. 1, článek Kněží půjdou vždy věrně s lidem. 


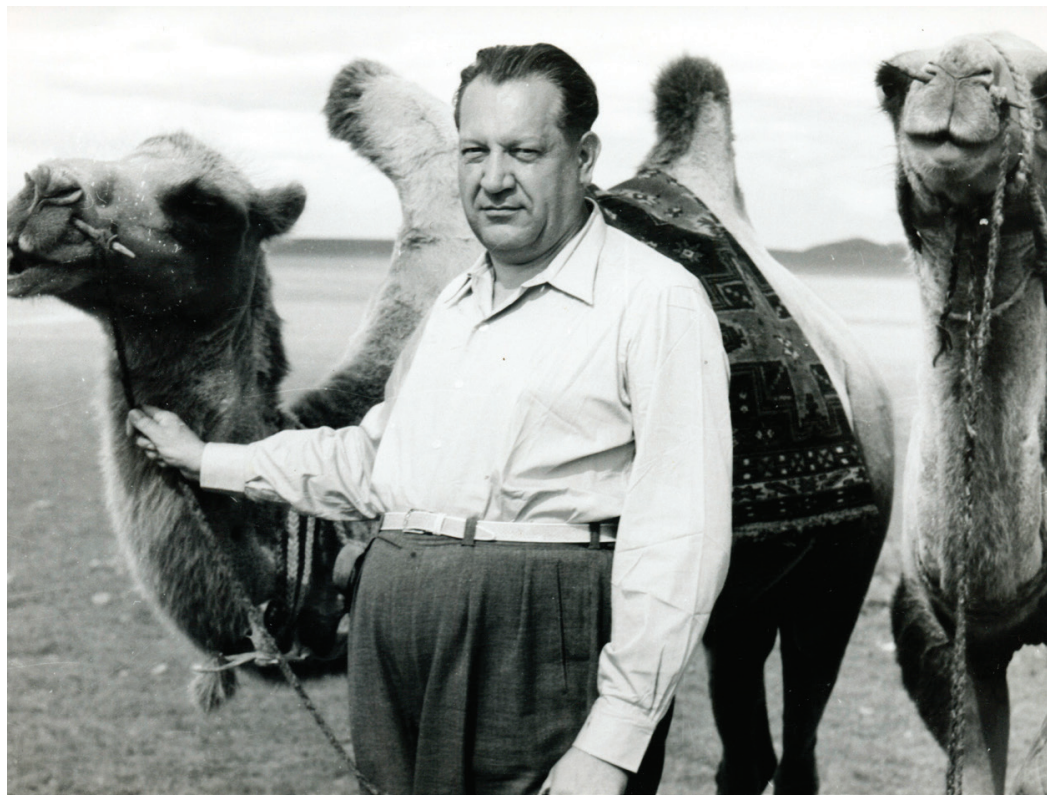

Obrázek 2 - Josef Plojhar s velbloudem při státní návštěvě Mongolska. Archiv autora.

dějin, kdy o únoru 1948 mluvil v superlativech bez známek jakýchkoliv chystaných změn. ${ }^{15}$

Teprve až $\mathrm{v}$ březnu se začíná pomalu ale jistě měnit situace uvnitř lidové strany. Ještě na začátku března pokračuje předseda ve své dosavadní publicistice, kde kritizoval predstavitele sudetoněmeckých krajanských organizací. ${ }^{16} \mathrm{O}$ pár dní později ovšem už samotný Plojhar reaguje na politické změny i v lidoveckém tisku. Jeho vyjádření jsou opatrná a mírná. ${ }^{17}$ Postupně uznává, že v minulosti došlo k chybám, které je zapotřebí napravit. Vzhledem ke své dosavadní činnosti nedokázal ovšem vystoupit ze svého stínu. Př́kladem může být Plojharův článek s př́íznačným názvem Chyby napravovat, jejž uveřejnila 17. března 1968 Lidová demokracie ${ }^{18}$ a který následně vyvolal značnou reakci u mnohých členů strany. Ve svém článku mimo jiné napsal: „Přehmaty, $k$ nimž v minulosti docházelo porušováním nebo svévolným výkladem socialistické zákonnosti, souvisely do značné míry s tím, že se dostatečnè neuplatñovaly principy socialistické demokracie ". ${ }^{19}$ A vyslovuje svůj souhlas i se svobodou politických názorů, což bylo v té době vyjádřeno populárním heslem pluralismus. ${ }^{20}$ Vývoj ovšem zrychluje. Ve straně jsou hybnou silou především redaktoři Lidové demokracie, kteří usilují o změny. ${ }^{21}$ Ve svých vystoupeních hovoří nejen o potřebách transformace politického systému, ale i o demokratizaci a zkrátka o všem, co si tehdejší členové a př́znivci lidovců přáli slyšet. Jejich články vyvolávají u členů „mírnou“ odvahu kriticky vystupovat a požadovat změny. Konec zimy a počátek jara 1968 se tak nese ve znamení velkých nadějí projevujících se mimo jiné

15 Lidová demokracie, roč. 24, č. 55, 25. února 1968, s. 1, článek J. Plojhara Významný mezník novodobých dějin.

16 Lidová demokracie, roč. 24, č. 62, 3. března 1968, s. 1, článek J. Plojhara Nepoučili se z dějin.

17 Lidová demokracie, roč. 24, č. 69, 10. března 1968, s. 1, článek J. Plojhara Tvưrčí partnerství.

18 Lidová demokracie, roč. 24, č. 76, 17. března 1968, s. 1, článek J. Plojhara Chyby napravovat.

19 Tamtéź.

20 Lidová demokracie, roč. 24, č. 76, 17. března 1968, s. 3, článek Plnou volnost názorové výměně.

21 Lidová demokracie, roč. 24, č. 75, 16. března 1968, s. 1, článek Stanovisko redaktorů Lidové demokracie, členů ČSL. 
i prudkým nárůstem členské základny. Členové povzbuzeni tímto vývojem jak na místních, tak na vyšších úrovních, tj. okresní a krajské přicházejí se svými požadavky a o těchto snahách informuje postupně i stranický tisk. ${ }^{22} \mathrm{~V}$ aktuálních protestech vedle jiného zaznívá i požadavek obměny stranického vedení.

Na stranických schůzích se objevuje názor, že předseda strany má vyvodit osobní odpovědnost a spolu s ním mají odejít i někteří jeho nejbližší spolupracovníci. Stranické organizace volají po novém stranickém sjezdu, žádají urychlené svolání ústředního výboru ČSL a kritické zhodnocení práce celého vedení atd. V druhé polovině měsíce března pak není pomalu dne, kdy by se neobjevila v Lidové demokracii nějaká více či méně skrytá výzva k změnám uvnitř vedení. Jen málokdo se v té době předsedy zastával. Vyskytly se ovšem i takoví: například OV ČSL v Příbrami se nechalo slyšet, že předsedou má Plojhar zůstat, protože „,má zásluhy“. ${ }^{23}$ Následující den bylo však toto usnesení zpochybněno. ${ }^{24}$ Celá mediální kritika gradovala na konci měsíce, kdy lidovecký tisk již otevřeně hovořil o stranické krizi a na stránkách novin se diskutovalo, jak stranické problémy řešit. ${ }^{25}$ Kritika současného předsedy se objevovala nejen na stránkách Lidové demokracie, ale také na stránkách Důvěrníka, tj. periodika určeného pro vnitřní potřebu strany. Zde snad kritika byla ještě otevřenější a v některých okamžicích možná i bizarnější, jako by platilo, že po řadě let se uvolnila stavidla, a tak se můžeme dočíst, že jedna členka například navrhovala, aby kritizovaný předseda odešel jako misionář do rozvojových zemí. ${ }^{26}$

Dochované interní materiály, ale i paměti lidoveckých funkcionářů nám umožňují nahlédnout pod pokličku tohoto vývoje. Vedení tehdejší lidové strany přemýšlelo, jak se k celé věci postaví.

Pro vládnoucí KSČ byl klíčovým měsícem leden, kdy byl do čela strany zvolen Alexander Dubček. Pro lidovce to byl nakonec až březen. A tak zatímco komunisté hovořili o polednové době jako času politických změn, lidovci mluvili o předbřeznové, respektive pobřeznové době.

Ze začátku se ještě zdálo, že i tyto změny předseda ustojí. Čelný funkcionář strany Jiří Rubín ${ }^{27}$ ve svých pamětech na to vzpomíná: „Plné noviny, nová orientace, začaly první mitinky. Projevovalo se to také u nás v lidové straně. Na první poradě krajských tajemniků, která se konala někdy koncem února nebo začátkem března, přišel Plojhar na poradu krajských tajemnikio a vedoucich ústředních pracovníků Charitasu. Tam přišel s tím, že je nový

22 Lidová demokracie, roč. 24, č. 79, 20. března 1968, s. 1, článek Podporují požadavky demokratizace ČSL. Nebo Lidová demokracie, roč. 24, č. 80, 21. března 1968, s. 1, článek Otevřené hlasy k demokratizačnímu procesu v ČSL.

23 Lidová demokracie, roč. 24, č. 87, 28. března 1968, s. 1, článek K vývoji situace v Čs. straně lidové.

24 Lidová demokracie, roč. 24, č. 88, 29. března 1968, s. 1, článek Další organisace pro odstoupení předsednictva ČSL.

25 Lidová demokracie, roč. 24, č. 88, 29. března 1968, s. 3, článek Jak vyřešit současnou krizi v Čs. straně lidové.

26 Di̊věrnik, roč. 21, č. 7, 5. dubna 1968, s. 10. článek Otevřené vyjádření názorů členstva naší strany.

27 Jiř́ Rubín (1921-2012), funkcionář a politik. Vyučil se autoklempiř̌em v mladoboleslavské Škodovce, kde byl pak několik let zaměstnán. Od mládí se angažoval v katolickém hnutí (skautingu) a od r. 1945 byl členem ČSL; 1945-1948 okresní tajemník ČSL v Mladé Boleslavi; 1948-1949 krajský tajemník ČSL v Liberci; 1950-1970 tajemník ústředního sekretariátu ČSL v Praze a 1968-1970 poslanec ČNR a člen předsednictva Ústřední rady odborů. Na začátku normalizace ze strany vyloučen a až do důchodu pracoval jako hlídač na parkovišti. Po listopadu 1989 se stal poslancem ČNR (1990-1992) a v roce 1996 inicioval vznik společnosti Emila Háchy. 
politický vitr, na který jsme dlouho čekali, jak naše lod' potřebovala tento vítr do plachetasi tímto způsobem to prezentoval. Řekl, že mèl i schůzku s novým prvním tajemnikem ÚV KSČ Dubčekem, že má projednáno, že budeme mit volný nábor členů bez Národni fronty, bez schvalováni našich kandidátů, že se strana rozroste tak, jak potřebuje. Ličil nám, co všechno má s Dubčekem předjednáno. Že také strana se bude moci postavit na vlastní nohy, pokud jde o tisk, rozšírení Lidové demokracie, vrátíme se $k$ většimu vydání Křest'anské ženy, ${ }^{28}$ že to, co nám chybí, všechno si vynahradíme, otevřeme si prodejny ve všech krajich, budeme mít volnost knih atd. Bojovali jsme za každý výtisk, který nám dali, dnes budeme moci pricházets slastní iniciativou podle potřeby, abychom byli skutečně stranou křestanskou a stranou věř́cího lidu. My jsme z toho byli tenkrát nadšeni. Pamatuji se, jak přišel s nadšením, že na rohu Karlova náměstí a Resslovy ulice [...] byla volná plocha, metro tam ještě nebylo. Ta plocha byla dost neupravená. Říkal, že má dojednáno, že tam bude postaven di̊m lidové strany, jaký má CDU v Dráżd'anech a v Berlině, abychom se mohli mezinárodně - když nám sem jezdí návštěvy - mohli vyrovnat jako rovnocenný politický partner, že už má předem předjednán souhlas a pracuje se na projektech, že tam vyroste obrovská budova... Musím říci, že tenkrát jsme byli všichni nadšeni. Nenapadlo nás, co všechno přijde, jak se bude situace vyvíjet. "29

Plojharova byt' opožděná reakce $\mathrm{v}$ rámci prvních týdnů pražského jara tak byla pozoruhodná. Kritizoval finanční zabezpečení tajemníků a nedostatky předchozí doby. Zdálo se, že si svoji funkci bez problémů udrží. Opak byl pravdou. Jeho pozice se stávala velmi rychle neudržitelnou. Zatímco oslavy dvacátého výročí února 1948 proběhly ještě plně v režii stávajícího vedení, tak následující dny a týdny se začaly nést v rovině spontánních, až lavinovitých protestů proti stávajícímu vedení. Vyplývá to ze záznamů tehdejších porad vedení na nejrůznější úrovni. Stejně tak je nalezneme ve zprávách pamětníků a pozorovatelů.

Březen a duben 1968 byly nakonec pro tehdejšího předsedu zásadními měsíci. A především v březnu se rozhodovalo o jeho bytí a nebytí ve vedoucí funkci. Dubnové události už pak představovaly jakousi dohru pro jeho ministerské, respektive vládní působení.

Jeho pád způsobila nespokojenost řadových členů, kteří se začali ve velkém ozývat. Plojhar se však nevzdával a o svoji pozici dlouho bojoval. V prvních dnech se snažil čelit kritice a jako zkušený politik různě manévroval a taktizoval. Jeho pokusy o zvrácení vývoje situace ovšem vycházely naprázdno. Nepodařilo se mu zabránit živelnému hnutí volajících po reformách, které vygradovalo na konci března 1968 na zasedání ÚV. Zprávy o konaných schůzích místních, okresních a krajských organizací to plně potvrzovaly. ${ }^{30}$ Předseda a jeho blízcí spolupracovníci si začali uvědomovat neodvratnost celého vývoje směřující $\mathrm{k}$ jeho pádu. Předseda chtěl zabránit svolání mimořádného pléna ÚV ČSL na konci března 1968, ale to se mu nepodařilo. Předtím na všech schůzích zaznívaly požadavky, aby se ČSL konečně probudila z letargie a přistoupila k radikálním reformám a mimo jiné se objevovaly i požadavky rehabilitovat někdejší pronásledované členy strany.

28 Křest'anská žena bylo původně periodikum Svazu katolických žen a dívek v ČSR vycházející v letech 19191941. V roce 1948 obnovila ČSL vydávání tohoto časopisu určeného pro ženy a časopis vycházel v letech 1948-1954.

29 Paměti Jiřího Rubína, nestránkováno, strojopis (paměti v držení autora).

30 Srovnej K. KonEČNÝ, Československá strana, Praha 2019, s. 14-15. 
Rozhodující pak pro další Plojharovo setrvání ve funkci byla březnová porada krajských tajemníků svolaná na 26. 3. 1968, o které nám zanechal svědectví Jiří Rubín: „Přišlo dubnové zasedání (správně březnové - pozn. aut.), a to už byly plné noviny svobody, změn atd. Plojhar opět zahájil poradu krajských tajemniků. Byli pozváni tušim i krajští předsedové a pracovníci ústředi. Tam

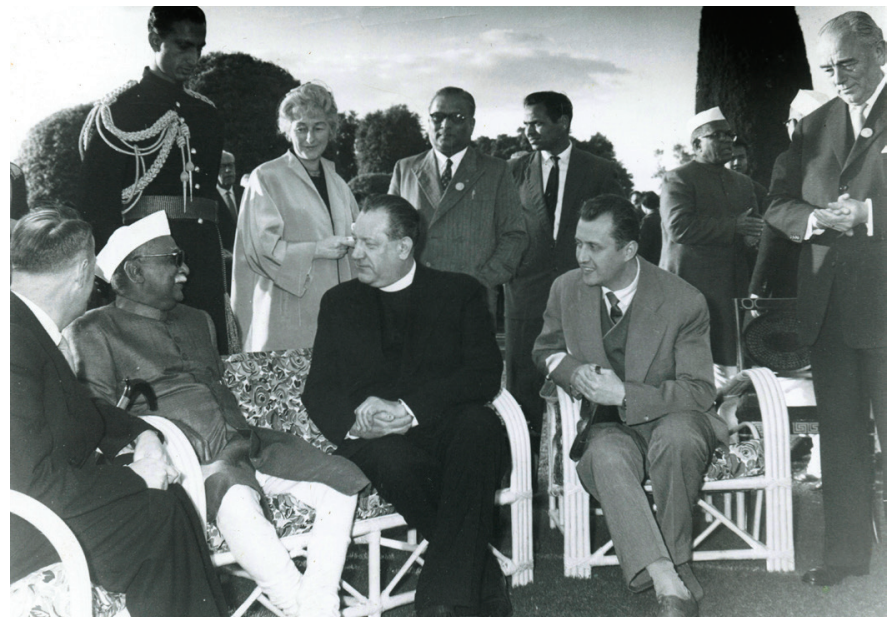

Obrázek 3 - Josef Plojhar při setkání s indickým prezidentem R. Prasádem v roce 1961 př́ státní návštěvě Indie. Archiv autora.

Plojhar začal, jak to všechno rozjiždíme, kritizoval minulý režim, jak nám krajští tajemníci Národní fronty zakazovali činnost, jak nás hlídali, jak nám zavírali naše tajemníky. Měl dlouhý projev, po kterém přišla odezva. Přihlásil se jako první krajský tajemník v Praze Rudolf Rejhon, ${ }^{31}$ poslanec Národniho shromážděni [...] Řekl je to krásný projev pana předsedy, ale že pan předseda si musí uvědomit, že už nemůže stát v čele, že změny, které budou, nemůže provádět stejná osoba, která s tím dvacet let souhlasila. Nastal souhlasný potlesk tajemniki. " 32

Rudolf Rejhon ve svém projevu přirovnal ČSL ke káře, která se dostala do bahna, a všichni jí musí pomoci, aby se z něho vyprostila.

Proti Plojharovi vystupovali nejen členové, nižší funkcionáři a tajemníci strany. Rostoucí opozice byla podporována i řadou stranických novinářu a našla svůj prostor na stránkách tehdejší Lidové demokracie. ${ }^{33}$

Proces Plojharova odchodu z vedoucích funkcí byl postupný a pozvolný. A probíhal na pozadí tehdejších celospolečenských událostí, jako byla prezentace nového generálního tajemníka ÚV KSČ Alexandra Dubčeka a postupný odchod Antonína Novotného ze všech politických funkcí a hledání nového kandidáta na úr̆ad prezidenta republiky. Mimochodem lidovci bez jakýchkoliv výhrad přijali komunistický návrh na obsazení prezidentského úřradu Ludvíkem Svobodou. ${ }^{34}$

Poprvé vyzvali krajští tajemníci k odstoupení přítomného předsedu a s ním i celé před-

31 Rudolf Rejhon (1915-2005), úředník a politik. 1937-1946 mzdový účetní u firmy Jaromír Středa v Kutné Hoře. Od roku 1945 člen ČSL. 1950-1968 krajský tajemník ČSL v Pražském (Středočeském) kraji

32 Paměti Jiřího Rubína, nestránkováno, strojopis (paměti v držení autora).

33 Srovnej např. Lidová demokracie, roč. 24, č. 75, 16. 3. 1968, s. 1. Stanovisko redaktorů Lidové demokracie, členů ČSL. LD, roč. 24, č. 83, 24. 3. 1968, s. 1. Poskytnout prostor pro ozdravující proud v Čs. straně lidové. Stanovisko redakce Lidové demokracie. LD, roč. 24, č. 85, 26. 3. 1968, s. 1. Otevř́ít dveře demokratickým proudům v ČSL. Rezoluce stranických orgánů.

34 Archiv KDU-ČSL, f. Klub poslanců, Zápis ze schůze stranické skupiny poslanců NS - členů ČSL z 29. března 1968. Na této schůzi byl přijat všeobecný souhlas lidoveckých poslanců s kandidátem Ludvíkem Svobodou na post prezidenta republiky. 
sednictvo na mimořádné poradě širšího vedení strany a krajských tajemníků 26. března $1968 .{ }^{35} \mathrm{Na}$ samotný akt nakonec došlo o necelý týden později na zasedání pléna ústředního výboru ČSL, které se konalo poslední březnový víkend 30. a 31. března 1968 v paláci Charitas na Karlově náměstí.

Ze záznamu o průběhu jednání je patrné, že od samého počátku provázela setkání nervozita. Hlavním bodem jednání bylo vystoupení dosavadního předsedy Josefa Plojhara. I přes nepř́źznivé okolnosti jeho projev vyzníval stále sebevědomě. Zmínil v něm nadcházející změny. Účastníkům sděloval, že se sešel s novým generálním tajemníkem Alexandrem Dubčekem, který ho ujistil, že ČSL nebude již např́íště ,převodní pákou usnesení ÚV KSČ “. Ve svém projevu přiznal, že vývoj poměrů v naší vlasti po únoru a zvláště od r. 1950 „,deformoval [...] počáteční, krásný, upř́mný a otevřený program “36 a on stejně tak jako celá strana stál před rozhodnutím, zda stranu rozpustit, anebo pokračovat i za ztížených a ne zcela vyhovujících podmínek.

Z jeho projevu na zasedání ÚV ČSL bylo patrné, že si Plojhar uvědomoval, že bojuje o svoji budoucnost. Jeho projev byl nejen sebevědomý, ale i bilanční. Své setrvání ve funkci obhajoval tím, že se po celou dobu snažil získat maximum pro svoji stranu a pro věřící spoluobčany. Mimo jiné uvedl, že jeho zásluhou je v Praze v úřadu správce pražského arcibiskupství biskup František Tomášek, ${ }^{37}$ a to přestože byl na počátku komunistické éry tajně vysvěcen a následně umístěn na několik let do internačního kláštera Želiv.

Ve svém projevu dále zastával názor, že pro mnohé při nejlepší vůli nemohl nic udělat a podle jeho názoru by nikdo nesvedl víc. Bilancoval tak vlastně svoji kariéru. I když to nebylo patrně úmyslně. Chtěl tím jen své spolustraníky přesvědčit a získat jejich důvěru, aby mohl pokračovat dál. Při svém proslovu řekl posluchačům i že: ,jestliže bilancujeme uplynulých těch 20 let života a práce naši strany i jednotlivých funkcionářu naši strany i představitelu naši strany, a jest-li smím dodat i mé osoby, bych jenom poprosil o spravedlivé posuzování jak chyb nedostatků a nebylo jich málo, tak i úspěchů, kterých bylo docíleno. “

V té souvislosti odmítal kritiku, která zaznívala na stránkách tehdejší Lidové demokracie. Odmítal útoky jednotlivých stranických kolegů. Kritizoval především články Emila Vojance ${ }^{38}$, který na něj útočil. Podle něj to bylo ovlivněno tím, že se Vojanec nestal ministrem a nástupcem na předsednickém křesle po úmrtí Aloise Petra. Plojhar rovněž kritizoval redakci Lidové demokracie, že mu nedávají dostatečný prostor k vyjádření.

35 Archiv KDU-ČSL, f. PÚV ČSL, kart. 3/9. O schůzi předsednictva referovala druhý den rovněž Lidová demokracie. LD, roč. 24, č. 86, 27. 3. 1968, s. 1, článek ÚV ČSL svolán na tuto sobotu. Zasedalo předsednictvo ÚV ČSL.

36 Archiv KDU-ČSL, f. ÚV ČSL (nezpracováno), zápis z jednání ÚV ČSL 30--31. března 1968. Z tohoto zápisu pocházejí i další citace mluvčích vystupujících na tomto jednání.

37 František Tomášek (1899-1992), duchovní, pedagog a teolog. 1949 tajně vysvěcen na biskupa olomoucké arcidiecéze. 1951-1954 internován v Želivi; 1954-1965 administrátor farnosti Moravská Huzová; 1965-1977 apoštolský administrátor pražské arcidiecéze a 1977-1991 pražský arcibiskup. 1977 jmenován kardinálem.

38 Emil Vojanec (1899-1971), odborář a politik. Za první republiky působil nejprve jako četník a ve třicátých letech se stal funkcionářem a zaměstnancem křest’ansko-sociálních odborů. 1946-1954 poslanec NS. Po druhé světové válce zastupoval ČSL v ROH. V druhé polovině padesátých let se dostal do konfliktu s Josefem Plojharem a na konci roku 1959 byl donucen se vzdát politické činnosti a odejít do důchodu. V době pražského jara patřil mezi největší kritiky Josefa Plojhara. O návrat do politiky již neusiloval mimo jiné i ze zdravotních důvodů. 
Údajně mu větší prostor poskytli novináři ze zahraničí či z některých domácích zdrojů než novináři zastupující lidovecký tisk. Na adresu Lidové demokracie řekl, že neposkytuje objektivní zpravodajství: ,zcela otevřeně ř́kám, že bylo tendenčně ř́zeno a vybráno to, co se hodilo, potlačováno to, co se nehodilo". ${ }^{39}$

Zajímavé je, že se zastával studentů ze strahovských kolejí, kteří svými protesty vlastně zažehli politické změny, vedoucí k lednovému zasedání ÚV KSČ, k pádu Antonína Novotného a nástupu Alexandra Dubčeka: „Já bych chtěl říci jenom toto: Kdyby mně bylo 18 nebo 19 let a kdybych byl studentem ze strahovských kolejí a kdyby se nám bývalo po ní nesvítilo, neměli jsme teplou vodu, nemohli jsme si v době zkoušek ani uvařit snídani, ani studovat, poněvadž byla tma, já bych býval nejenom se této protestní schĩze účastnil, ale podle mé povahy bych býval asi toto spoluorganizoval. "40

Své spolustraníky také ujistil, že pečlivě studuje všechny podněty, které mu přicházejí na stůl z celé strany, a upozornil, že činnost ČSL sledují i lidovci, kteří v exilu vytvořili svoji exilovou lidovou (Křest’ansko-demokratickou) stranu. Jeho bilanční projev byl velmi dlouhý. Členové ÚV mu ještě více méně ze setrvačnosti zatleskali. Následně se rozvinula debata, do které se zapojila řada členů ÚV. Celá záležitost se protáhla do dalšího dne. Někteří se s předsedou pokoušeli polemizovat. Šéfredaktor František Touška ${ }^{41}$ se zastával celé redakce Lidové demokracie. Poukázal na to, že otevřenost má i své výsledky, protože deník má v těchto dnech náklad 180000 výtisků, což znamenalo nárůst o 25000 výtisků více než před 14 dny.

Řada členů vyzývala současného předsedu, aby odstoupil. Nepřítomný člen širšího vedení strany a poslanec Jan Niederle ${ }^{42}$ poslal z motolské nemocnice dopis, v němž požadoval, aby se nově zvolené vedení skládalo z čestných lidí, kteří budou „,nezatiženi minulostí a nepoplatní nikomu a ničemu ". ${ }^{43}$ Současně také předsedovi napsal, aby odstoupil a nebránil demokratizačnímu procesu. Někteří vystupující dokonce hovořili v souvislosti s předsedou o kultu osobnosti.

Pro samotného předsedu to muselo být asi v daný okamžik velmi hořké zklamání. Mnozí funkcionáři, již se na něj dř́ive obraceli s žádostí o pomoc a kteří $\mathrm{k}$ němu byli často až velmi servilní a patolízalští, najednou obracejí a jdou tvrdě proti němu. Jen málokdo se v tu chvíli zastal Plojhara, ale našli se i takoví. Většinou se jednalo o řadové členy širšího vedení. Václav Tomeš se nechal slyšet, že mnozí lidé, kteří využívali předsedu, se dnes k němu podle obracejí zády, a volají „ukřrižuj“. „,Ukřižuj, to je slovo, které nepatři do úst krestanů. Křestan má odpouštět a pomáhat. " ${ }^{44}$ Podobně se ho zastával i jeho blízký spolupracovník Ferdinand Brodský, který v souvislosti s předsedou vyzdvihoval intervence,

39 Archiv KDU-ČSL, f. ÚV ČSL (nezpracováno), zápis z jednání ÚV ČSL 30.-31. března 1968.

40 Archiv KDU-ČSL, f. ÚV ČSL (nezpracováno), zápis z jednání ÚV ČSL 30.-31. března 1968.

41 František Touška (1918-1986), novinář a politik. Po středoškolských studiích spolupracoval 1940-1947 s nakladatelstvím Vyšehrad. 1948-1949 redaktor a filmový kritik Lidové demokracie. 1949-1963 zástupce šéfredaktora a 1963-1970 šéfredaktor Lidové demokracie. 1968-1970 poslanec ČNR. Na začátku normalizace činěn odpovědným za publicistiku Lidové demokracie v době pražského jara.

42 Jan Niederle (1893-1982), odboráŕ a politik. Vyučil se zedníkem a krátce pracoval u Československých státních drah jako dělník. Od dvacátých let působil jako funkcionář a zaměstnanec křest’ansko-sociálních a později i sjednocených odborů. 1948-1971 poslanec NS a jedna z nejvýraznějších postav obrozené ČSL na Moravě.

43 Archiv KDU-ČSL, f. ÚV ČSL (nezpracováno), zápis z jednání ÚV ČSL 30.-31. března 1968.

44 Archiv KDU-ČSL, f. ÚV ČSL (nezpracováno), zápis z jednání ÚV ČSL 30.-31. března 1968. 
jež podnikal ve prospěch členů strany, a na zasedání řekl: „Sestry a bratři, slyšeli jsme v poslední době o našem bratrovi předsedovi mnoho zkresleného, mnoho nepravdivého a osobního. Je třeba .se vážně zamyslet nad celou jeho osobností, nad vykonaným dílem za daných možností a zabývat se chybami, které má každý člověk, každé lidské dílo. Každá chyba na exponovaném mistě se projevuje daleko výrazněji, nežli u místního činitele a chyb je tím více, čím větši je pracovní angažovanost. " ${ }^{45}$ Podobně se ho zastával i Václav Pacner či poslanec Josef Gemrot, ${ }^{46}$ kteří patřili mezi jeho nejvěrnější spolupracovníky.

Řada delegátů také vystupovala v tom smyslu, že Plojhar během těch dvaceti let sice dokázal zachránit lidovou stranu, ale je třeba, aby nyní uvolnil místo. Ing. Miroslav Svoboda, který byl později známý tím, že spolu s několika dalšími poslanci se zdržel při hlasování o smlouvě o pobytu sovětských vojsk na zasedání, řekl: „Došli jsme k závěru, asi $k$ takovému, že bratr předseda strany se nesporně a jaksi historicky zasloužil o zachováni naši lidové strany jako takové. Že prostě během těch 20 let provedl naši stranu lidovou takovým úskalím, přes které by jiná politická organizace nevydržela. Toto místo bude jaksi nesmazatelně zapsáno v historii naši strany a za to myslím, že to zhodnotíme v závěru našeho jednání. "47

Celé jednání nakonec dopadlo tak, že v očích většiny straníků zprofanovaný a kritizovaný předseda a s ním i několik nejbližších spolupracovníků a členů předsednictva sice odstoupili z vedení, odmítli ale zároveň rezignovat na členství v plénu ústředního výboru a na poslanecké mandáty v Národním shromáždění.

Plojhar v danou chvíli celou věc považoval takříkajíc jen za prohranou bitvu a nikoliv válku. Svoji předsednickou funkci obětoval, protože měl naději na zachování své ministerské funkce. Ústřední výbor ho po jeho odstoupení zvolil čestným předsedou a současně schválil, aby nadále zastupoval stranu ve vládě.

Po tomto aktu na zasedání vystoupil nový čestný předseda a poděkoval členům za zvolení. Ve svém děkovném projevu citoval jak prezidenta Zápotockého, tak Masaryka. Prvního, když přiznával své chyby. Přímo řekl, že prezident Zápotocký mu řekl, že každý člověk dělá chyby a jen ten, kdo nic nedělá, nic nezkazí. A druhého, když zavzpomínal na to, jak coby mladý student vstupoval do nově vzniklé strany v Českých Budějovicích, když se v roce 1919 zakládala její místní organizace. A dále bilancoval celý svůj život ve službách ČSL. Mimo jiné připomínal svůj pobyt v koncentračním táboře a také to, že po osvobození mluvil na oslavách prvního máje v Dachau jako zástupce ČSL. Na závěr delegátům sdělil, že je naprosto zdráv a že chce i nadále pokračovat ve své ministerské funkci.

Po jeho odvolání byl na předsednické místo zvolen dlouholetý místopředseda ČSL Antonín Pospíšil. ${ }^{48} \mathrm{~V}$ tajných volbách získal 49 hlasů z padesáti delegátů, tj. 98 \% odevzda-

45 Archiv KDU-ČSL, f. ÚV ČSL (nezpracováno), zápis z jednání ÚV ČSL 30.-31. března 1968.

46 Josef Gemrot (1903-1979), horník a politik. 1948-1971 poslanec NS a 1952-1965 generální tajemník ČSL.

47 Archiv KDU-ČSL, f. ÚV ČSL (nezpracováno), zápis z jednání ÚV ČSL 30.-31. března 1968.

48 O jeho volbě blíže viz Lidová demokracie, roč. 24, č. 91, 1. dubna 1968, s. 1, článek Antonín Pospíšil předsedou ČSL. Antonín Pospíšil (1903-1973), odborový předák a politik. Původním povoláním soustružník. Od mládí se angažoval v křest’ansko-sociálních odborech, kde působil od třicátých let (např. 1936 tajemník křest'anských odborů v Pardubickém kraji. Po sjednocení odborů pracoval jako pracovník NOÚZ a později ROH. 1948-1951 generální tajemník ČSL a 1951-1968 místopředseda ČSL. Stranu zastupoval rovněž i na vládní úrovni. 19511958 ministr dopravy a 1958-1960 ministr energetiky a vodního hospodářství; 1960-1964 místopředseda NS a 1968-1973 předseda ČSL. 
ných hlasů. Kdo byl tím jediným hlasem? Zdali to byl Antonín Pospíšil, či Josef Plojhar, nebo někdo jiný, můžeme jen spekulovat. Spolu s ním byl zvolen i nový místopředseda ČSL a generální tajemník. Novým místopředsedou se stal ing. Miroslav Svoboda ${ }^{49}$ a generálním tajemníkem se stal Jan Pauly. ${ }^{50}$

Ti ovšem již nezískali tak výraznou podporu jako nový předseda. ${ }^{51}$ Současně bylo také potvrzeno nové předsednictvo strany, kde vedle předsedy, čestného předsedy, místopředsedy a generálního tajemníka zasedlo ještě zvolených osm členů strany. ${ }^{52}$ Současně bylo přijato i nové programové prohlášení, které dávalo tušit nastávající změny ve straně, ale i v celé společnosti. ${ }^{53}$

V pobřeznové době ve stranické lidovecké centrále zavládla zvláštní atmosféra. Mimo jiné pro ni byla charakteristická právě silná kritika odstupujícího předsedy, která skutečně do jisté míry připomínala kritiku kultu osobnosti. Podobné tendence ale bylo možné sledovat v dané době nejen v lidové straně, ale vůbec v rámci komunistického Československa. Jisté srovnání v tomto ohledu snese i př́klad výše jmenovaného Antonína Novotného, který byl odstraněn nejprve z pozice generálního tajemníka ÚV KSČ a později pod vlivem okolností byl donucen odstoupit i z funkce prezidenta republiky

Začínalo pražské jaro a lidé toužili po změně. Navíc věřili, že onen čas s sebou přinese reformy a změnu celé společnosti. Je úžasné pozorovat, jak se dobré ideály spojovaly se špatnou praxí a každodenností. Mnozí vycítili př́ležitost a šanci ke svému zviditelnění, a tak nastal př́iznačný čas honu na čarodějnice, kterého se nejvíce účastnili ti, kteří ještě na začátku roku byli vůči předsedovi nejvíce servilní. Ale to už tak v politice mnohdy bývá. Je to boj o moc, který v tomto př́ípadě byl zahalen do souboje frází o další orientaci strany, kdy v projevech členů vedení zaznívaly v zásadě v této záležitosti dva hlavní názory. První byla obava, aby ve straně nepřevládl „pravicový směr"54 a strana byla do-

49 Miloslav Svoboda (1922-1988), rolník, agronom a politik. 1960-1968 poslanec NS a 1968-1970 poslanec ČNR a SL FS. Při hlasování o smlouvě o dočasném pobytu sovětských vojsk se zdržel hlasování. Na začátku normalizace byl donucen odejít z veřejného dění.

50 Jan Pauly (1910-1986), úředník a politik. Pocházel z tradiční lidovecké a katolické rodiny. Jeho strýc byl P. Jan Pauly (1869-1944), kněz, katolický spisovatel a politik. Jan Pauly mladší byl absolventem Svobodné školy politických nauk a 1932-1941 pracoval v Zemské bance. 1942 zatčen gestapem a až do konce války vězněn. Po válce aktivní v ČSL, kde zastával řadu funkcí v rámci Středočeského kraje. 1968-1970 generální tajemník ČSL; 1969-1971 ministr bez portfeje federální vlády a 1968-1970 poslanec ČNR a 1969-1970 poslanec SN FS. Představitel obrodného proudu v ČSL, který musel na začátku normalizace odejít z vysoké politiky.

51 Nový místopředseda Miroslav Svoboda získal 42 hlasů (tj. 84 \%) a Jan Pauly obdržel 36 hlasů (tj. 72 \%).

52 Předsednictvo strany tvořili dále: Josef Hronovský, Anna Míková, Jaroslav Sláva, Anděla Sukupová, Josef Škoda, Richard Škrobánek, František Toman, František Touška. I tito členové byli voleni ÚV ČSL. Nejvíce hlasů, 50 (tj. 100 \%), získal Josef Škoda.

53 O výsledcích jednání informovala veřejnost Lidová demokracie 1. dubna 1968. Blíže viz Lidová demokracie, roč. 24, č. 91, 1. dubna 1968, s. 1, článek A. Pospíšil předsedou Čs. strany lidové a článek Usnesení ústř̌edního výboru ČSL. Programové prohlášení ČSL přijaté ÚV ČSL na svém zasedání 30-31. března 1968 si mohli přečíst v dobovém tisku. Čtenáři se mohli s jeho obsahem seznámit 1. dubna 1968. Blíže viz Lidová demokracie, roč.24 č. 91, 1 dubna 1968, s. 1, článek Programové prohlášení Čs. strany lidové.

54 Srovnej vyjádření člena ÚV ČSL Václava Kypty, který 31. března 1968 na zasedání ÚV ČSL řekl: , ,..dnes nejde jen o osoby, dnes nejde jen o to, kdo z nás měl menši, či větši zásluhy, dnes jde o existenci strany jako takové. O existenci strany, která vycházi z křest’anského světového názoru, s křest’anským smýšlením, křest’anské etiky a krest'anské morálky. “ Dále pak pokračoval v tom smyslu, že na rozdíl od předsedy strany nemá strach ze vzniku nějaké levicové křest’ansko-sociální strany, ale naopak z pravicové, která by měla 


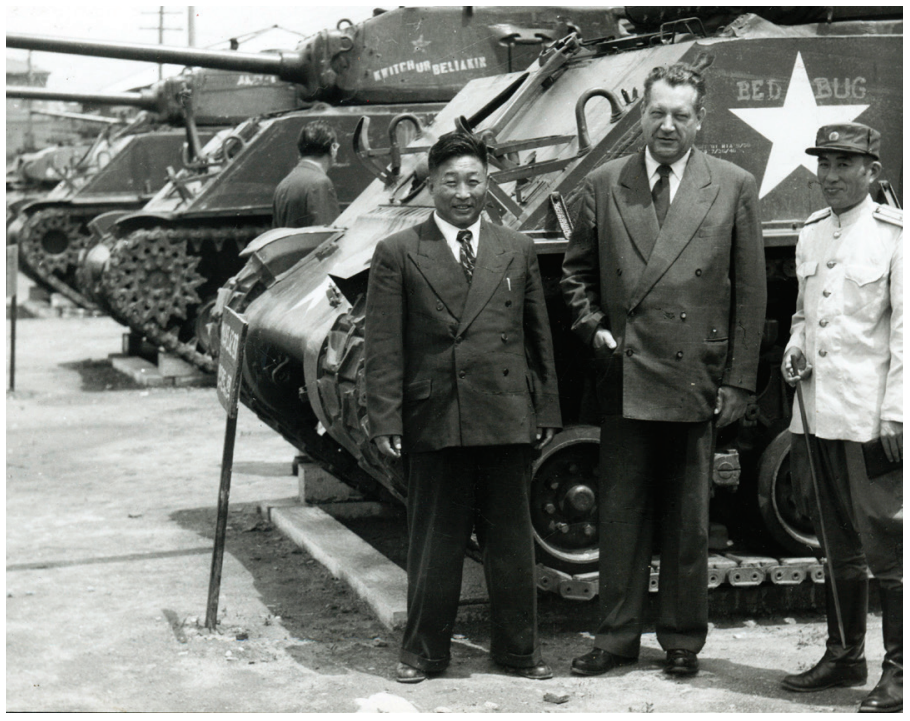

Obrázek 4 - Josef Plojhar při oficiálni návštěvě Severní Koreje s doprovodem před ukořistěnými americkými tanky. Archiv autora. statečně levicová a socialistická. A druhý názor zaznívající na jednání, aby si uchovala strana svůj hlavní smysl, tj. vést věřící , $k$ socialistickému rozvoji naší ze$m e \check{e}$ “. 55

Jeden $\mathrm{z}$ pamětníků a zaměstnanců sekretariátu ČSL Václav Ryneš to ve svých pamětech popsal slovy: „Poznal jsem ty, kteři odstavili J. Plojhara. Pozoroval jsem nejistotu, křě̌ovitost, bezradnost, nekoncepčnost $i$ zmatenost.

Zároveñ jsem začal pocitovat zvláštnost atmosféry a prostředí, ve kterém jsem se najednou ocitl. Zjištoval jsem, ale spiše citově vnímal strojenost, neuprímnost, vychytralost, vyčkávání, klamná slova, zatajování, úskočnost a řadu dalšich prozatím ve společenském životě pro mne nepríliš známých metod a jednání. "56

Ještě 31. března 1968 se zdálo, že Plojharův ústup ze slávy nebude až tak výrazný. Na zasedání ústř̌edního výboru ČSL byl Antonínem Pospíšilem, tedy nástupcem v předsednické funkci, navržen a jednomyslně potvrzen čestným předsedou a současně byl potvrzen ve funkci ministra. A o tomto byla informována následně i komunistická strana, jejíž vedení následujícího dne, 1. dubna 1968, potvrdilo Josefa Plojhara ve funkci ministra. ${ }^{57}$ Bylo to považováno za jakési odškodnění, které jak si ještě ukážeme, netrvalo dlouho, ale ani to v politicky vypjatých momentech nemusí být nic mimořádného. Situace se velmi rychle mění, a to byl právě tento příklad - za pouhý týden mělo být vše jinak.

Plojhar poděkoval na závěr jednání všem př́itomným za poctu být prvním čestným předsedou v historii strany.

Jeho konec v předsednické funkci a současně jmenování do čestné funkce vyvolalo značnou pozornost dobového tisku, ale především celé strany. Jiří Rubín na celou věc vzpomíná slovy: , Jakmile Lidová demokracie oznámila, že Plojhar je čestným předsedou strany, rozvinula se strašná plejáda protestů ze všech krajů a okresů. Do ústředí přišlo asi

podporu mezi částí katolického duchovenstva. Blíže viz Archiv KDU-ČSL, f. ÚV ČSL (nezpracováno), zápis z jednání ÚV ČSL 30..-31. března 1968.

55 Tak to definoval František Toman ve svém projevu na zasedání ÚV ČSL 31. března 1968. Archiv KDU-ČSL, f. ÚV ČSL (nezpracováno), zápis z jednání ÚV ČSL 30.-31. března 1968.

56 Citováno dle K. KonEČNÝ, Československá strana, s. 22. Srovnej Václav RYNEŠ, Všední dny naděje a beznaděje v letech 1967-1971; in Pavel Marek a kol., Jan Šrámek a jeho doba, Brno 2011, s. 506.

57 Srovnej Národní archiv v Praze (dále jen NA Praha), f. předsednictvo ÚV KSČ 1966-1971, sv. 66, aj. 78. Zápis z jednání předsednictva ÚV KSČ 1 . dubna 1968. 
120 petic, které žádaly, aby ústředni výbor zrušil své rozhodnutí a zbavil ho funkce čestného předsedy. “To výbor učinil a „,tím také Plojhar přestal prakticky chodit na ústředí. Pro něj přestala tím okamžikem strana existovat. "58

Nespokojenost s rozhodnutím vedení strany byla patrná i z dochované korespondence uložené v lidoveckém archivu. Do ústředí chodila řada dopisů nejen z místních, okresních a krajských organizací, ale i od řady prostých jednotlivců. Negativní reakce byly patrné hned i na stránkách dobového tisku. Druhého dubna se nechali např́klad redaktoři Lidové demokracie slyšet, že vítají zvolení nového vedení. K předešlému však byli kritičtí a prohlásili: „,vedoucím pracovníkům, kteři nestači na úkoly dneška, je třeba umožnit čestný a důstojný odchod, přiměrený k jejich zásluhám, $k$ poméru jejich dobrých skutků a chyb. Domniváme se však, že rozhodnutí ÚV ČSL o zvolení dr. J. Plojhara čestným předsedou ČSL a souhlas s výkonem funkce ve vládě, přihliži pouze k zásluhám a opomíji chyby. Nemůžeme se s ním ztotožnit. "59

Další dny se objevovaly pravidelně již radikálnější zprávy, které odsuzovaly rozhodnutí udělit Plojharovi titul čestného předsedy. ${ }^{60}$ Tisk informoval o tom, jak nejen jednotlivé místní organizace, ale i ty okresní a krajské protestovaly a hovořily o rozhořčení a nespokojenosti s rozhodnutím vedení. ${ }^{61}$ Protesty proti Plojharovi jako ministru zdravotnictví zaznívaly i z jiných míst. Například ústřední výbor Odborového svazu pracovníků ve zdravotnictví se obracel na ÚV KSČ s žádostí, aby bylo zváženo další působení Plojhara ve funkci. ${ }^{62}$

Josef Plojhar odmítal opustit post ministra zdravotnictví, který zastával kontinuálně dvacet let od února 1948. Následující dny se pak nesly ve znamení toho, že nové vedení strany přemýšlelo, jak ho právě tohoto úradu zbavit. Celá věc se řešila nejen na stranické úrovni, ale také na vládní úrovni, respektive na úrovni vztahů mezi KSČ a ČSL. Dne 6. dubna 1968 se sešlo nové vedení ČSL, které tajně hlasovalo o tom, zda má stranu i nadále zastupovat Josef Plojhar. Většina hlasujících se vyjádřila, že tomu tak nemá být, a následně bylo velkou většinou hlasů rozhodnuto př̌i dalším hlasování, že Plojhar nebude již ani čestným předsedou. ${ }^{63}$

Představu o tom, jak celé jednání probíhalo, si můžeme udělat z dochovaného záznamu a průběhu jednání ÚV ČSL z 6. dubna 1968. Tehdy zahájil v zasedací síni Charitasu jednání nový předseda strany Pospíšil, který oznámil členům, že jednáním o sestavení nové vlády byl pověřen Oldřich Černík, ${ }^{64}$ a celou věc možná tak trochu alibisticky prezentoval

58 Paměti Jiřího Rubína, nestránkováno, strojopis (paměti v držení autora).

59 Lidová demokracie, roč. 24, č. 92, 2. dubna 1968, s. 1, článek Plná důvěra novému předsednictvu.

60 Srovnej např́iklad Lidová demokracie, roč. 24, č. 94, 4. 4. 1968, s. 1, článek Nesouhlas s čestným předsednictvím; Lidová demokracie, roč. 24, č. 95, 5. dubna 1968, s. 3, článek Stanovisko organizací k dr. J. Plojharovi; Lidová demokracie, roč. 24, č. 96, 6. 4. 1968, s. 1, článek Organizace se vyjadřují k rozhodnutí ÚV ČSL. Polovičaté řešení neprospělo.

61 Lidová demokracie, roč. 24, č. 94, 4. 4. 1968, s. 1, článek Plná podpora novému vedení ČSL. KV ČSL v Severočeském kraji o dr. h. c. J. Plojharovi.

62 Lidová demokracie, roč. 24, č. 94, 4. dubna 1968, s. 1, článek Zdravotníci žádají odvolání ministra.

63 Lidová demokracie, roč. 24, č. 97, 7. dubna 1968, s. 1, článek Sjezd ČSL bude na podzim a článek Usnesení ústředního výboru ČSL.

64 Oldřich Černík (1921-1994), komunistický politik. Vyučený soustružník. Od roku 1945 člen KSČ. V padesátých letech předseda KNV v Ostravě a v šedesátých letech zastupoval stranu v československé vládě. 
tak, že je to primárně přání komunistické strany. Hned na začátku připomněl přání Alexandra Dubčeka personálně proměnit složení nové vlády, a že veřejnost očekává změny. To byl vážný argument. Současně Pospíšil připomněl na začátku jednání i výrok tehdy oblíbeného komunistického činovníka Josefa Smrkovského, který na zasedání ÚV KSČ řekl, že obsazení vedoucích míst lidmi, kteří doopravdy chtějí demokratizaci naší společnosti, lidmi kvalifikovanými, zodpovědnými i čestnými je považováno za první větší praktickou prověrku, toho, zda strana chce skutečně splniti to, co její představitelé a řadoví funkcionáři po lednových diskuzích slibují. ${ }^{65}$ To vše bylo podstatné pro straníky zvyklé rozhodovat na základě direktiv KSČ. Současně poukázal i na jistou časovou tíseň v jednání, protože vedení lidové strany bylo pozváno na jednání s Oldřichem Černíkem v pravé poledne, a rovněž připomněl Plojharův slib, že se podrobí rozhodnutí ústředního výboru, at' bude jakékoliv. To vše bylo předzvěstí výsledku jednání, které s ohledem na velké protesty řadového členstva nemohlo dopadnout jinak. Ministr Plojhar nebyl na začátku jednání přítomen. Důvodem jeho nepřítomnosti bylo právě probíhající jednání československé vlády. Generální tajemníky Jan Pauly ještě v době, než dorazil Plojhar, oznámil členům možné návrhy na uvolněný post ministra zdravotnictví, přičemž z jeho slov byl patrné, že nejsilnějším kandidátem na tuto funkci je Vladislav Vlček.

Po př́ichodu na zasedání vedení ČSL informoval J. Plojhar jeho účastníky, že byla podána demise celé vlády, a tlumočil Černíkovu prosbu, aby pokud dojde k personální změně v osobě ministra, tak aby lidovci navrhli za sebe odborníka z řad lékařu. Dále do jednání již vůbec nezasahoval. Hlasování nakonec dopadlo v jeho neprospěch. Velkou většinou bylo rozhodnuto, že nemá již být nadále ministrem zdravotnictví (43 hlasů pro usnesení a jen 4 proti). Současně vedení zvolilo Vladislava Vlčka jako kandidáta na uvolněné místo ministra.

Někteří lidovci se ještě před jednáním zabývali myšlenkou, zda se nepokusit prosadit, aby ve vládě byli znovu dva členové strany, z nichž jeden by mohl být Plojhar př́ípadně i s jiným určením. Tato varianta však neprošla. Stejně dopadla i otázka čestného předsednictví Josefa Plojhara, jež byla většinou 35 hlasů anulována. Plojhar, celou věc vůbec nekomentoval. ${ }^{66}$

S tímto výsledkem pak vedení ČSL seznámilo komunisty a následně nový prezident Ludvík Svoboda jmenoval 8. dubna 1968 novou vládu, kde už nebyl ministrem zdravotnictví Josef Plojhar, ale Vladislav Vlček, jenž měl pověst slušného člověka a odborníka. ${ }^{67}$

Jiří Rubín si vzpomínal, jak se celá věc přihodila, že Plojhara nahradil v ministerské funkci právě Vlček „Padly čtyři nebo pět návrhi̊. Na prvním místě byl profesor Pařizek z IKEMU v Krči, který dostal dokonce Řád práce [...] Ten že je nejlepši pro funkci ministra zdravotnictví. Na druhém místě, kdyby to náhodou nevzal, byl dr. Kolominský, ředitel Lá-

1960-1963 ministr paliv a energetiky. 1963-1968 místopředseda vlády a předseda Státní plánovací komise. 1968-1970 předseda vlády a 1968 též ministr zahraničních věcí. 1971 vyloučen z KSČ.

65 Archiv KDU-ČSL, f. ÚV ČSL (nezpracováno). Zápis ze zasedání ÚV ČSL, které se konalo 6. dubna 1968. 66 Archiv KDU-ČSL, f. ÚV ČSL (nezpracováno). Zápis ze zasedání ÚV ČSL, které se konalo 6. dubna 1968.

67 Vladislav Vlček (1912-1979), farmaceut a politik. Vystudoval farmacii a př́rodní vědy na PřF UK Praha.

Později působil jako farmakolog v nejrůznějších firmách a podnicích (např. 1949-1952 v podniku Penicilin v Roztokách u Prahy). Od r. 1952 pak působil ve Výzkumném ústavu antibiotik. Členem ČSL byl od roku 1946. 1968 ministr zdravotnictví ČSSR a 1969-1971 ministr zdravotnictví ČSR. K jeho osobě Lidová demokracie, roč. 24, č. 99, 9. dubna 1968, s. 1, článek Životopis Vladislava Vlčka. K osobě Vladislava Vlčka viz též Michal PeHr a kol., Cestami krest'anské politiky. Praha 2007, s. 290. 
zeňského léčebného ústavu I. P. Pavlova z Karlových Varů, který byl praktikujicím křest’anem. Doma měl asi šest nebo sedm dětí. Měl však dobré jméno jak v Karlových Varech, tak $i$ ve straně. Na třetím mistě bylo vysloveno jméno dr. Vlčka, magistra farmacie, který se podílel na výzkumu a výrobě našeho prvního vlastního penicilinu. Jako poslední návrh byl dr. Antošik, náměstek ústředního ředitele Federálni správy nemocenského pojištěni na Ústřední radě odborů. “ Rubín dál ve svých pamětech uvádí, že se postupně jednalo se všemi kandidáty s tím, že jednání byl přítomen i Plojhar, který mlčel a k věci se nevyjadřoval. „Bylo svoláno ještě předsednictvo strany [...] Byl tam pozván dr. Pařízek. Seděl tam asi dvacet minut, řekli mu, že by měl být ministrem zdravotnictví. Řekl, že za žádných okolností funkci nepřijme, že je vědeckým pracovnikem, práce ho baví, že nemá smysl pro organizační věci a politiku vůbec ne. Načež Pospíšil jako úřadující předseda zahř́mal: Ale bratře doktore, máme také nějakou stranickou disciplínu, potřebujeme tě alespoň na přechodnou dobu. Dr. Pařizek odvětil, že je členem strany, že platí př́spěvky, souhlasí s jejím programem, doufá, že nedělá straně žádnou ostudu, dokonce chodi každou nedèli s rodinou do kostela jako věřici křest'an. Takže neví, proč by musela být nad ním disciplína. V̌̌ádném př́padě to nevezme a odporoučel se... Také se jednalo s čislem $d v e ̌-d r$. Kolominským. Já jsem měl za úkol z ústředí zatelefonovat mu a spojit se s ním $v$ té věci. Mluvil jsem s ním a on mi hned řekl, že do Prahy nepojede, že je to zbytečné, že za žádných okolností funkci ministra zdravotnictví nevezme, že má proto své osobní a zejména rodinné di̊vody. Řekl, že jeho paní je Němka, že má v Německu plno př́buzenstva. Je otázka, jestli by to nékomu nevadilo. Ale at’ vyř́dím, že do Prahy nepojede a funkci neprijme. "68

Jako poslední přišel podle vzpomínek Jiřího Rubína na řadu dr. Vlček, který nakonec přislíbil svoji spolupráci. „Na řadu přišel dr. Vlček, který už byl zpracován Dušanem Čulikem, dosavadním tajemnikem ministra Plojhara, který pracoval na ministerstvu zdravotnictví. Na ústředí... měl posazeného Vlčka a šil do něj, že se nemusí ničeho bát, že mu se vším pomůže, do všeho ho zasvětí. Ale Vlček se k tomu nijak neměl kladně. Když ho povolali do předsednictva, snažil se jim vysvětlit, že se na funkci nehodí, že ani o ni moc nestojí. Připomínalo mi to, jako když Háchu přesvědčovali na prezidenta. Nakonec rekli, že nikoho jiného nemají, sice měli Antošíka v záloze, ale tomu už bylo kolem 60 let a nevypadal zrovna mladistvě, chodil pomalu, mluvil rozvážně. Nebyli s ním moc nadšeni. Byla to jen záloha, kdyby všichni selhali. S ním se prakticky ani oficiálně nejednalo. Byl jenom připraven jako náhradník. "69

Oficiálně kandidátů na nového ministra zdravotnictví bylo ještě více, než uvádí Jiří Rubín ve svých pamětech. Na předsednictvu ÚV ČSL 5. dubna 1968 padala tato jména: Vladislav Vlček, Jiří Kolominský, František Toman, Miroslav Svoboda, Jiř́i Kabelka, František Hanzal a Karel Antošík. ${ }^{70}$ Novým ministrem zdravotnictví se stal Vladislav Vlček a posledním okamžikem ministra Plojhara ve funkci bylo setkání s novým prezidentem Ludvíkem Svobodou, který přijal starou vládu 8. dubna 1968 v odpoledních hodinách jako projev díků za její činnost. Při setkání se starou dosluhující Lenártovou

68 Paměti Jiř̌́ho Rubína, nestránkováno, strojopis (paměti v držení autora).

69 Paměti Jiř́ho Rubína, nestránkováno, strojopis (paměti v držení autora).

70 Dưvěrnik, roč. XXI, č. 8, 18. dubna 1968, s. 7, článek V duchu nových myšlenek. 
vládou poděkoval především končícím ministrům Plojharovi a Neumanovi za české socialisty, který rovněž končil ve svém ministerském angažmá. ${ }^{71}$

Pro Plojhara osobně byl takový vývoj opravdu nečekaný. Nechtěl se smírit s touto situací a bránil se, co mu síly stačily. Neměl ovšem šanci běh věcí jakkoli zvrátit. Za dvacet let se odpor proti němu natolik nashromáždil, že mu nemohl za tehdejší politické situace vzdorovat. Nastalo pro něj zvláštní období. Byl zbaven vrcholných funkcí a tuto situaci nesl velmi těžce. Stal se z něho oficiálně důchodce a mimo jiné se musel po dvaceti letech vystěhovat z vládní vily a hledat si nové bydlení v Praze. Stěhování se protáhlo až do léta 1968. ${ }^{72}$ Jeho požadavkům nebylo lehké vyhovět. Žádal byt v centru Prahy, a nakonec se celá věc vyřešila přestěhováním do bytu $\mathrm{Na}$ nábřeží Kyjevské brigády 8 , kde žil až do konce svého života.

Jeho konci v úřadu ministra zdravotnictví věnoval pozornost jak domácí, tak zahraniční tisk. Je zajímavé, že Vatikánský rozhlas na rozdíl od situace počátkem padesátých let se ministrovým koncem již nezabýval.

S jeho koncem ve vrcholné politice byl spojen i konec funkcí ve vedení některých velkých organizací, které Plojhar kontinuálně zastával řadu let. Politické změny jej připravily o funkce jak v čele Mírového hnutí katolického duchovenstva, tak i v čele Svazu československo-sovětského přátelství, jehož byl místopředsedou. Ústup z těchto funkcí byl postupný, ale byl nastartován právě pražským jarem.

Jedinou funkci, kterou si uchoval, byl jeho poslanecký mandát, i když i o ten měl přijít. V celém průběhu jara a léta 1968 se objevovaly požadavky, aby bud’ odstoupil, anebo byl zbaven mandátu. Toto téma rozebírala řada rezolucí, které přicházely novému stranickému vedení, a kauza získávala i pozornost dobového tisku. Jaro a léto 1968 byly pro Plojhara osobně velmi těžké. Stal se z něj v podstatě někdo, koho bychom mohli označit s jistou nadsázkou jako „,bývalého člověka“. Ztratil se z povědomí veřejnosti a ani sám neusiloval o nějaké výraznější zasahování do veřejného dění.

Události srpnové invaze do Československa pro něj představovaly novou naději, když doufal, že se bude moci vrátit do nejvyšší státní politiky. Po srpnu 1968 se pokoušel o návrat do vedoucí stranické funkce a Jiří Rubín k tomu ve svých pamětech napsal: „Plojhar začal si zvát do svého bytu lidi, které chtěl zpracovávat. "73 A následně popisoval, jak se s ním v tuto dobu setkala řada lidoveckých poslanců. A začal také aktivněji vystupovat a kritizovat poměry pražského jara a naopak pozitivně se vyjadřoval o invazi a především o počátcích normalizačního vývoje. Přes svoje kontakty a vliv se mu to nepodařilo. Stál sice v čele „konzervativní“ frakce v ČSL a spolu s ním usilovali o návrat i někteří jeho blízcí spolupracovníci, jako byl Václav Pacner. Restaurace moci se ovšem nekonala. Co se stalo? Jak to bylo možné?

71 Alois Neuman (1901-1977), právník, úředník, učitel a politik. Osobní přítel ministra Plojhara. Od mládí činný v národně socialistické straně. 1935-1939 poslanec NS a 1937-1939 starosta Českých Budějovic. Za války 1939 zatčen a 1939-1945 vězněn (Buchenwald). Po osvobození 1945-1946 předseda MNV České Budějovice a 1945-1976 poslanec NS a SL FS. 1948-1960 ministr pošt a 1960-1968 ministr spravedlnosti. 1960-1968 předseda Československé strany socialistické.

72 Vládní vilu v Bubenči (adresa Bubenečská 59/731) měl Plojhar opustit k 8. červenci 1968. Plojhar žádal o náhradní byt. Chtěl dvojgarsoniéru I. kategorie ve vnitřní Praze s garáží pro jeho osobní vůz. Blíže viz NA Praha, f. Ministerstvo zdravotnictví, k. 84.

73 Paměti Jiřího Rubína, nestránkováno, strojopis (paměti v držení autora). 
Odpověd' na položené otázky se hledá těžko. Na první pohled by se zdálo, že nastaly ty nejlepší šance, aby se on i jeho blízcí spolupracovníci vrátili do vedení strany. V čele strany se ovšem zformovalo nové vedení kolem Rostislava Petery ${ }^{74}$, který měl s Josefem Plojharem dlouhodobě napjaté vztahy, ${ }^{75}$ ač oba byli velmi dobře zapsáni v KSČ, a Rostislav Petera patřil dokonce mezi tajné členy KSČ. Vzestup Rostislava Petery a jeho skupiny byl ovlivněn především tím, že byl sympatický novému vedení KSČ v čele s Gustávem Husákem a odpovídal jeho představám o podobě normalizační konsolidace. Navíc Husák považoval Plojharovo odstoupení za záležitost generační výměny. ${ }^{76}$ Svou úlohu v tom hrála i Státní bezpečnost, která si od Rostislava Petery v danou dobu slibovala více než od bývalého ministra.

Výsledkem tak nakonec bylo, že se Plojhar sice nedostal do své původní funkce, ale pod nátlakem normalizátorů se jeho pozice alespoň výrazně zlepšila. Publikoval mnohé články ve stranickém tisku na téma obhajoby soudobého vývoje a československo-sovětských vztahů, pod kterými byl jako někdejší předseda podepsán.

Navzdory protestům regionálních organizací strany se pod nátlakem KSČ a jejích složek pro řízení stranické práce muselo vedení ČSL podvolit a kooptovat J. Plojhara do předsednictva ÚV ČSL, a navíc mu vrátit titul čestného předsedy. Toto rozhodnutí formálně přijalo plénum ústředního výboru ČSL 4. prosince 1969, čímž ČSL vstoupila do ostré fáze normalizace a , konsolidace "77 vnitrostranických poměrů, kdy nastaly ve vedení strany normalizační čistky. Reprezentanti pražského jara v čele ČSL museli postupně dříve nebo později odejít, např́ḱlad generální tajemník ČSL Jan Pauly.

Plojharův návrat vyvolal velkou lavinu protestů. Stranické vedení bylo na konci roku 1969 zavaleno velkým množstvím dopisů, které protestovaly proti návratu bývalého předsedy. Př́íkladem může být dopis 23 členů lidové strany a účastníků zemědělského školení na Ústřední politické škole v Klínci: „,Jako straničtí př́slušníci ze všech krajů Vám při dnešní

74 Rostislav Petera (1909-1980), novinář a politik. 1937-1940 redaktor brněnského lidoveckého deníku Den. Po osvobození působil v redakci Národní obrody v Brně a 1948-1963 šéfredaktor Lidové demokracie. Pro neshody s Josefa Plojharem odešel ze služeb ČSL a 1964-1970 pracoval jako novinář mimo stranu. Po Plojharově pádu se vrátil do strany. 1970-1973 generální tajemník a 1973-1980 předseda ČSL, 1971-1980 ministr vlády ČSR

75 Jiří Rubín ve svých pamětech vysvětluje př́íčinu dlouhodobě napjatých vztahů tím, že Petera odmítnul uveřejnit oslavný článek na Antonína Pospíšila, který slavil 55 let v roce 1958. K průběhu celého sporu napsal: „,Plojhar se rozčlilil a ř kl, aby to tam dali druhý den. On mu odmitl, že jsou to noviny a ne vzpomínky, že druhého dne nebude nic uveřejňovat. Došlo ke strašnému napětí a - ̌̌ekl bych - $k$ osobnímu střetu mezi Plojharem jako predsedou strany a mezi tehdejším šéfredaktorem Lidové demokracie Rostislavem Peterou. Táhlo se to asi týden. Končilo to velkými bouřemi až na ústředním výboru Národni fronty, kde měl Petera velkou zastánkyni v generálni tajemnici Národní fronty Kleňhové-Besserové (Ladislava Kleňhová-Besserová 1912-1997, pozn. aut.), která Plojharovi tvrdila, že je to bouře ve sklenici vody, at’ si to kouká uklidnit. Jenže Plojhar odjel za Novotným na Hrad - to vím od tehdejšiho Plojharova náměstka a jeho kamaráda Ferdinanda Brodského, který potom druhý den vykládal práteliom, jak to vitězně dopadlo, že šéf je šéf-a tam mu řekl: Bud'to já, nebo on. Řekl, že to mysli velmi vážně, že by jeho autorita úplně padla. Novotný jako generálni tajemník a president se mu snažil podobně jako Kleňhová-Besserová ř́ci, aby se to nějakým způsobem urovnalo. Když viděl, že Plojhar trvá na svém, zavolal před Plojharem Kleňhovou-Besserovou, aby dala ruce od toho pryč, at' pustí Peteru. Takže se stal Touška, jeho náměstek šéfredaktorem. “ Paměti Jiřího Rubína, nestránkováno, strojopis (paměti v držení autora).

76 Srovnej např́iklad Karel LöBL, Naděje a omyly. Vzpomínky na onu dobu, Praha 2012, s. 374.

77 Tento termín pochází se studie Karla Konečného a považuji ho za velmi výstižný pro popis celé situace. Srovnej např. K. KonEČnÝ, Československá strana, Praha 2019, s. 113. 
složité politické situaci vyjadřujeme naši podporu a důvěru. Mezi našimi členy se rozšírila zpráva, že uvažuje o návratu do stranického vedení br. dr. Plojhar, bývalý předseda ČSL, $t$. č. $v$ důchodě. Otevřeně prohlašujeme, že by nebylo osudnějšího kroku pro naši stranu, kdyby tento funkcionár mél znovu politicky pracovat. Z našeho reálného pohledu by to znamenalo v současné době ohrožení důvěry naprosté většiny straníků v celý ústřední výbor ČSL. Znamenalo by to zajisté $i$ značný rozvrat $v$ radách lidovců, což nesmíme dopustit. Máme porozumění pro Vaši složitou práci, ale otázkám zásadním musíme čelit společně, odhodlaně a otevřeně. "78 V podobném duchu přicházelo obrovské množství dopisů na vedení strany.

Karel Konečný ve své práci o vývoji ČSL v době pražského jara připomíná v té souvislosti dopis ze Znojma, který obdržel generální tajemník Jan Pauly dva dny před plénem ústředního výboru. V dopisu se ke kauze J. Plojhara vyjádřilo 90 delegátů rozšířené schůze pléna $\mathrm{OV}$ ČSL, kteří uvedli, že zastupují 33 místních a městských organizací registrujících 1240 členů. „Nepríjemným překvapením pro nás byl článek v Lidové demokracii, č. 292, s úvodníkem J. Plojhara, kde je Plojhar uveden jako mistopředseda SČSP. ${ }^{79}$ Pokud byl článek míněn jako pokusný balónek ke zjištění reakce členstva na opětovné uplatněni Josefa Plojhara v ČSL, pak se vším dưrazem prohlašujeme, že si nejen nepřejeme reaktivaci Dr. Plojhara v ČSL, ale naopak žádáme, aby byl zbaven všech funkcí, ale i členství v ČSL. Jestliže KSČ zbavila Antonína Novotného členství v ÚV KSČ a nepripustila jeho návrat do politického života ani na stránky Rudého práva, pak je v zájmu konsolidace ČSL, aby zbavila členství v ÚV i jeho spoluvinika za deformace minulých let Dr. Plojhara. Kdyby měl být Dr. Plojhar naši straně vnucován, pak by to mělo za následek, že velký počet poctivých a čestných členů by naši stranu opustil a tisk, který by přinášel jeho články, by byl odmítán. Zasiláme toto usnesení redakci LD, PKV [předsednictvu krajského výboru - pozn. aut.] v Brně a PÚV ČSL v Praze. "80

Reakcí na jeho stranickou rehabilitaci a návrat čestné funkce byl i odchod řady členů z ČSL. Podle interních stranických statistik v této době odešlo přibližně tisíc členů ze strany, a nejméně dalších 200 členů bylo kvůli protestům následně vyloučeno. ${ }^{81}$

Pozice Josefa Plojhara $v$ časech normalizace byla zvláštní. Na jedné straně se ocitl na vedlejší koleji. Na druhé straně ho normalizační režim respektoval a prokazoval mu úctu. Bývalý, respektive čestný předseda byl i nadále věrný své politické koncepci. Vystupoval na její obhajobu, ale do nejvyšších pater československé politiky se již nedostal.

Nebyly realizovány ani úvahy o tom, že by se mohl stát naším vyslancem v SSSR či v NDR. Husákovo vedení se rozhodlo Plojhara odstavit. Až do své smrti zůstal ovšem čestným předsedou ČSL. V této funkci se pravidelně účastnil stranických sjezdů, setkání ústředního výboru atd. Současně byl i poslancem FS a bylo o něj dobře postaráno. Jako čestný předseda ČSL dostával plat, ${ }^{82}$ a vedle důchodu pobíral ještě odměnu za svoji poslaneckou činnost. V období let 1969-1971 byl poslancem za volební obvod Praha 6 - Břevnov. Později zastupoval moravské volební obvody. V letech 1971-1976 byl zvolen za Jihomoravský kraj a poslední své volební období zastupoval obvod Kroměříž-Gottwaldov (Zlín). V parlamentu

78 Srovnej Karel KoneČnÝ, Československá strana, s. 112. Archiv KDU-ČSL, f. PÚV ČSL 1969, k. 3/10. Dopisy. 79 Lidová demokracie, roč. 25, č. 292, 12. 12. 1969, článek Nerozborné přátelství: Dr. Josef Plojhar, místopředseda ÚV SČSP.

80 Blíže viz Karel KoneČnÝ, Československá strana s. 114.

81 K. KoneČnÝ, Československá strana, s. 116. Archiv KDU-ČSL, f. PÚV ČSL 1969, k. 3/10.

82 Tento plat mu byl vyplácen jako měsíční odměna ve výši 2500,- Kč od 16. prosince 1969. 
byl v letech 1969-1971 členem Výboru pro styk se socialistickými zeměmi a ve své poslanecké činnosti se i nadále zabýval zahraniční činností. Byl členem zahraničního výboru a místopředsedou meziparlamentní unie, kde byl členem československo-rakouské skupiny. ${ }^{83}$

Čas od času i publikoval, a to především v Lidové demokracii, která otiskovala jeho články takříkajíc na tradiční témata, jako bylo československo-sovětské spojenectví. V roce 1974 pak vydal vzpomínkovou práci na koncentrační tábor Buchenwald. ${ }^{84}$ Kniha má přes dvě stě stran a Plojhar ji možná trochu nezvykle rozdělil na tři základní části. V první části připomíná minulost Výmaru a všech významných postav, které v historii tohoto města působily (Bach, Herder, Schiller a další). Až v druhé části se dostává ke svým vzpomínkám na koncentrační tábor. Poslední část knihy je asi nejdiskutabilnější. Rekapituluje zde poválečný vývoj ve světle rozvoje socialistických zemí. Plojhar se také v této etapě svého života účastnil nejrůznějších besed a setkání. Mediální pozornost byla věnována i jeho narozeninám. ${ }^{85}$

Plojhar ovšem postupně omezoval své aktivity. Jednání vedení strany či parlamentu nebo dalších organizací se účastnil s menší intenzitou. Svůj podíl na tom mělo jistě i zklamání, že se mu nepodařilo znovu získat významnější postavení. Začalo se u něj projevovat zhoršující se zdraví. Ubývalo sil, př́iležitostí a aktivit. Svoji rétoriku ovšem nezměnil. V roce 1969 vystoupil proti provádění soudních rehabilitací, které před svými kolegy odsoudil a označil za ,velkou aféru“, a při té př́íležitosti také tvrdě vystoupil proti pokusům transformovat ČSL v KDS, o níž se vyjádřil, že to byla ,ilegální organisace zaměřená proti obrozené lidové straně“. A dál pokračoval v tom smyslu, že v cizině dodnes existuje řada lidí ,jako Tigrid, Procházka, Pecháček a Ducháček", ale i u nás je početná skupina jejich sympatizantů. Přičemž právě nastartované soudní rehabilitace z nich udělají „,mučedníky“.86

V podobném duchu vystupuje na půdě parlamentu i v ř́ínu 1969: „,My, poslanci, máme svatou povinnost ř́ci našim voličům, našemu lidu, plnou a jasnou pravdu o srpnu 1968. Jsem přesvědčen, že jako nás v roce 1945 zachránil Sovětský svaz před vyhlazením, tak nás v roce 1968 opět Sovětský svaz a socialistické země Varšavské smlouvy zachránily od kontrarevoluce, od protistátního puče, od strašlivé, krvavé občanské války. " $87 \mathrm{~V}$ prosinci 1969 se pak stal členem parlamentní skupiny, která měla pod vedením poslance Viléma Nového ${ }^{88}$ připravit analýzu činnosti NS a FS v letech 1968-1969. ${ }^{89}$

Setkával se se straníky, ale i s občany na nejrůznějších akcích. Stále agitoval. Tu a tam podnikal ještě některé cesty do zahraničí, ale přirozeně již neměl takovou mediální pozor-

83 Rovněž byl členem komise pro životní úroveň ÚV KSČ.

84 Blíže viz Josef PlojHar, Výmar-Buchenwald, Praha 1974.

85 Blíže viz NA Praha, f. 02/4, sv. 16, aj. 28, Usnesení 28. schůze sekretariátu ÚV KSČ z 22. února 1977. Gustáv Husák poslal blahopřejný dopis Josefu Plojharovi a ukládá V. Bejdovi ,zabezpečit přiměrenou publicitu“.

86 Archiv KDU-ČSL, f. Klub poslanců. Zápis ze schůze klubu poslanců FS a členů ČSL, která se konala 2. 12. 1969.

87 Projev Josefa Plojhara na společné schůzi SL a SN FS 15. ř́jna 1969. Blíže viz https://www.psp.cz/eknih/1969fs/ slsn/stenprot/003schuz/s003012.htm.

88 Vilém Nový (1904-1987), komunistický politik, spisovatel a novinár. V meziválečném období působil jako funkcionář KSČ a za války žil ve Velké Británii. 1949-1950 šéfredaktor Rudého práva. V padesátých letech pronásledován. 1950-1954 vězněn a později rehabilitován. V 60. letech se vrátil do veřejného dění. 1964-1976 poslanec NS a SL FS. Po srpnové invazi na sebe upoutal pozornost lživými prohlášeními ve věci smrti Jana Palacha.

89 V archivu KDU-ČSL je uloženo torzo zápisů z jednání této pracovní skupiny z roku 1970, ze které je patrné, že Josef Plojhar patřil mezi aktivní členy skupiny. Blíže viz archiv KDU-ČSL, f Klub poslanců (neuspořádáno). 
nost jako dřive. V roce 1976 naprríklad navštívil NDR. Jeho zdraví se postupně zhoršovalo, a tak ubývalo jeho veřejných vystoupení. Příznačné pro jeho politickou dráhu bylo, že se jeho život uzavřel v listopadu 1981 na recepci na sovětském vyslanectví, která se konala na připomínku oslav Velké ř́ínové revoluce. Byl to svým způsobem charakteristický konec pro tohoto politika. Ohledně jeho smrti panovala řada dohadů, pověstí, smyšlenek a fám. Její okolnosti byly tajeny. A tak např́klad Lidová demokracie den po smrti Josefa Plojhara uveřejnila pouze zprávu o konané recepci, ale ani slovo o jeho účasti na ní, natožpak smrti. ${ }^{90}$

To přiznává i lidovecký poslanec Jiří Rubín ve svých pamětech, kdy uvádí, že jsou různé verze Plojharova konce. Jedna varianta byla podle něj ta, že se mu udělalo špatně hned po př́chodu do budovy vyslanectví: , Ušatny, kdy se dávaly do úschovy oděvy, když se svléknul, zamotal se a spadnul přimo na zem vedle profesora Trávnićka, ${ }^{91}$ který byl předsedou ústředního výboru Národni fronty. Ten u něho konstatoval smrt. "92

Druhá varianta podle poslance Rubína byla ta, že Plojhar měl na recepci pozdvihnout skleničku na př́ipitek a přitom mu měla vypadnout sklenička $\mathrm{z}$ rukou a padnout do klína př́mo Trávníčkovi. Celou př́íhodu uzavírá Jiří Rubín konstatováním: „, Musím řici, že nevím, komu mám věrit, ale v každém př́padě odtud Plojhar odešel v rakvi. Tajnou cestou ho odváželi. Byla tam velmi ponurá nálada. "93 Ponurost nálady odůvodňoval pak Jiří Rubín ve svých pamětech tím, že Plojhar byl velmi oblíben v komunistických i sovětských kruzích, a navíc je vždy nepř́ijemné, když takto někdo zemře na slavnosti. Plojharovy ostatky byly odvezeny z vyslanectví a bylo ted' na pozůstalých, lidovcích a celému režimu, aby se důstojným způsobem rozloučili s člověkem, který pomáhal budovat stávající systém. Tomu odpovídal i rozsah rozloučení.

Zpráva o jeho smrti se ov československém tisku nakonec objevila bez jakýchkoliv podrobností, a jak to tak bývá, velmi pochvalně se zmiňovala o významu zemřelého. ${ }^{94} \mathrm{Jak} \mathrm{Li}$ dová demokracie, tak Rudé právo stejně jako další československý tisk věnovaly pozornost jeho smrti a zprávu převzal i zahraniční tisk. Lidová demokracie k jeho skonu napsala, že zasvětil svůj život práci ve prospěch naší vlasti a ,,budování socialistické společnosti. Naše strana, vlast a socialistická společnost ztrácejí jeho odchodem předního funkcionáře, neúnavného bojovníka za socialismus a mír, oddaného vlastence a internacionalistu, moudrého a prozíravého politika a vzácného člověka ".95

Plojharův pohřeb se uskutečnil 13. listopadu a měl dvě části. První byl oficiální, který byl uspořádán československým parlamentem za účasti tehdejšího vedení lidové strany, s ohledem na to, že Josef Plojhar byl stále poslancem FS. Celý obřad začal státní hymnou a poté národní umělkyně J. Petrovická přednesla verše F. Hrubína Zpěv lásky k životu. Za sněmovnu se s ním loučil tehdejší předseda Alois Indra. Hlavní projev měl místopředseda ÚV

90 Lidová demokracie, roč. 37, č. 263, 6. 11. 1981, s. 1, článek Recepce k 64. výročí VŘSR.

91 Tomáš Trávníček (1918-2008), lékař, vysokoškolský pedagog a politik. 1939-1942 vězněn nacisty jako student medicíny v koncentračním táboře Oranienburg. 1947 promován lékařem. 1965 jmenován profesorem, 1969-1990 poslanec SL a SN FS. V sedmdesátých a osmdesátých letech zastupoval KSČ v ústředním výboru Národní fronty.

92 Paměti Jiř́ího Rubína, nestránkováno, strojopis (paměti v držení autora).

93 Tamtéž.

94 Lidová demokracie, roč. 37, č. 264, 7. listopadu 1981, s. 1, článek Zemřel bratr Josef Plojhar.

95 Tamtéž. 
NF ČSSR Tomáš Trávníček. ${ }^{96}$ Po jeho projevu zazněly tóny třetí věty Smetanova kvarteta Z mého života a státní pohřeb byl zakončen Internacionálou. Poté byla rakev se zesnulým odnesena za zvuků Pochodu padlých revolucionářů z budovy parlamentu a následně převezena na Olšanské hřbitovy, kde se konal církevní obřad.

U rakve zesnulého, která byla zahalena státní vlajkou, se sešlo obrovské množství smutečních věnců a oficiálních hostů. Věnce poslalo nejen vedení ČSL, ale také řada vrcholných státních institucí. Věnec poslal prezident republiky, ale i vedení KSČ, Národní fronty, československá vláda, ale i řada dalších institucí. Před rakví byla vystavena také všechna vyznamenání, která obdržel zemřelý za svého života. Byly to především dva Rády Klementa Gottwalda, ${ }^{97}$ Rád 25. února a Čs. válečný kříž $1939 .{ }^{98}$ Mimo to se pohřbu účastnili i delegace spřátelených stran z východního bloku. ${ }^{99}$ Delegaci CDU z NDR vedl poslanec Lidové sněmovny, člen Státní rady a někdejší ministr zdravotnictví Max Sefrin. ${ }^{100}$ Mimo zúčastněné k úmrtí J. Plojhara pak kondolovalo obrovské množství jak domácích, tak zahraničních osobností.

Poté následoval církevní obřad. Tuto část mělo oficiálně na starosti tehdejší vedení lidovců. ${ }^{101}$ Př́ípravu církevního pohřbu provázely komplikace. Tehdejší pražský arcibiskup František kardinál Tomášek odmítl Josefa Plojhara pohřbít a současně si nepřál, aby se kdokoli z vyšších představitelů církve tohoto pohřbu účastnil, protože jejich účast by mohla být politicky zneužita. Pohřbu se nakonec zúčastnili tři kněží: Bohuslav Černocký, Josef Št'astný 102 a Jiří Huber. ${ }^{103}$

Vlastního obřadu se nakonec ujal Bohuslav Černocký, vyšehradský kanovník, který byl známý svojí dlouholetou spoluprací s KSČ. Už v roce 1946 kandidoval za KSČ do parlamentu za Ostravský kraj. Jiří Rubín ve svých pamětech uvádí, že tehdejší ministr kultury Klusák vyjednával s řadou duchovních, aby Plojhara pochovali. Jedním z nich podle Rubína byl kanovník Kořínek ${ }^{104}$. Ten se podle něj ,šel zeptat svého nadřizeného a ten mu řekl Chran̆ Pánbůh, abyste ho pohřbival vy jako svatovitský kanovník - to vím od Kořínka. Takže

96 O této věci bylo rozhodnuto na základě usnesení 19. schůze ÚV KSČ 10. listopadu 1981: , Sekretariát ÚV KSČ souhlasí s vysláním delegace ÚV NF na smutečni rozloučeni s Josefem Plojharem v čele s A. Indrou. Jménem všech se rozlouči T. Trávníček. "Blíže viz NA Praha, f. sekretariát ÚV KSČ 1966-1971, sv. 9, aj. 19.

97 První ŕád obdržel v roce 1955 a druhý obdržel v roce 1962.

98 Josef Plojhar za svého života dále získal Pamětní medaili k 20. výročí osvobození a vyznamenání za zásluhy o vznik Lidových milicí 1. stupně v roce 1958.

99 Srovnej např́klad Naše politika, roč. 11, 27. listopadu 1981, s. 2, článek k úmrtí čestného předsedy ČSL Dr. h. c. J. Plojhara.

100 Max Sefrin (1913-2000), východoněmecký politik. Od roku 1946 člen CDU, kterou zastupoval jak ve východoněmeckém parlamentu, tak na vládní úrovni mimo jiné jako ministr zdravotnictví.

101 NA Praha, f. sekretariát ÚV KSČ 1966-1971, sv. 9, aj. 19. Usnesení 19. schůze ÚV KSČ 1. listopadu 1981

102 Josef Štastný (1942-2009), 1964 vysvěcen na kněze. Následně působil jako duchovní v Praze a později na Plzeňsku.

103 Jiř́i Huber (nar. 1932), katolický kněz, teolog a emeritní děkan vyšehradské kapituly. 1956 vysvěcen na kněze. 1983 jmenován profesorem dogmatické teologie na Cyrilometodějské bohoslovecké fakultě v Litoměřicích. 1987 jmenován kanovníkem vyšehradské kapituly.

104 Václav Kořínek (1915-2007), katolický kněz a dlouholetý kanovník kapituly u sv. Víta. 1940 vysvěcen na kněze. Po vysvěcení působil jako duchovní v Sedlčanech a v řadě pražských farností. 1973 jmenován kanovníkem Metropolitní kapituly u svatého Víta. 
odmitl. “105 A dále pokračuje: „,Odmitli to i členové tehdejší organizace mírového hnuti"106... už nevím, jak se to jmenovalo. Odmitl to i karlštejnský děkan Dočekal, ${ }^{107}$ pokud vím. Myslím, že to odmitli i někteři kněži lidové strany z řad vyšších hodnostářù. Takže se nedostavili a odmitli prijít na pohřeb. "108

A tak pro ministra Klusáka nastala těžká chvíle - najít někoho, kdo Plojharův církevní pohřeb vypraví. Nakonec se uvolil Bohuslav Černocký, který „, to slíbil ministru kultury Klusákovi“. Jiří Rubín o něm mluvil jako o poslední naději pro ministra, který ,,věděl, že to je soudruh, takže [...] ten odpor tam bude nejmenší. Poslal pro něj svioj vlastní úřední automobil s řidičem a s obálkou, ve které byly penize. Řidič měl za povinnost tu obálku páteru Černockému odevzdat. Naložili ho na Vyšehradě, odvezli na Olšany a zase zpátky. "109

Církevní rozloučení se konalo v kapli na Olšanských hřbitovech. Průběh obřadu byl zcela běžný. Jménem strany se s ním rozloučil tehdejší př̀edseda ČSL Zbyněk Žalman. ${ }^{110}$ A za zvuku Beethovenovy skladby Anděl lásky byla rakev s tělesnými ostatky Josefa Plojhara uložena k poslednímu odpočinku. ${ }^{111}$

Pohřeb skončil a uzavřela se tak životní příběh nejdéle činného československého ministra zdravotnictví. O měsíc později, 15. prosince 1981, když se sešel tehdejší československý parlament poprvé od Plojharovy smrti, uctil ho na návrh Aloise Indry minutou ticha a povstáním všech přítomných poslanců. ${ }^{12} \mathrm{Na}$ uvolněné místo poslance FS nastoupil následujícího roku v doplňovacích volbách Josef Bartončík, který se později po revoluci stal Plojharovým nástupcem i ve funkci předsedy ČSL. ${ }^{113}$

Hrob Josefa Plojhara se nachází na Olšanských hřbitovech. Toto místo si vybral sám Josef Plojhar, když si na hlavní cestě na hřbitově zakoupil hrob, hned nedaleko vchodu po levé straně. Na černém kameni je nápis Dr. Josef Plojhar, předseda Československé strany lidové a ministr zdravotnictví Československé socialistické republiky. Tím doktorem se myslí jeho čestný doktorát, který mu udělila Teologická fakulta Univerzity Karlovy ještě předtím, než byla přestěhována $\mathrm{z}$ Prahy do Litoměřic. ${ }^{114}$ Plojhar byl na tento titul náležitě hrdý a přál si ho mít i na svém náhrobku.

105 Paměti Jiř́ho Rubína, nestránkováno, strojopis (paměti v držení autora).

106 Myslel tím hnutí Pacem in terris.

107 Jan Dočekal (1907-1988), katolický kněz. 1951 jmenován děkanem karlštejnské kapituly. 1953-1966 šéfredaktor Katolických novin.

108 Paměti Jiř́ho Rubína, nestránkováno, strojopis (paměti v držení autora).

109 Tamtéž.

110 Jeho projev byl uveřejněn v Lidové demokracii. Blíže viz Lidová demokracie, roč. 37, č. 270, 14. listopadu 1981, s. 1, článek Projev br. Zb. Žalmana.

111 Lidová demokracie, roč. 37, č. 270, 14. listopadu 1981, s. 1 a s. 3, článek Rozloučení s bratrem Josefem Plojharem.

112 Blíž viz https://www.psp.cz/eknih/1981fs/slsn/stenprot/003schuz/s003001.htm.

113 O celém průběhu slavnosti blíže viz Rostislav PETERA - Václav ŠNAJdR (eds.), Pocta bojovnikiom za mír. Praha 1951. 